\title{
A nappali lepkefauna vizsgálata Székesfehérváron (Lepidoptera: Rhopalocera)
}

\author{
HudÁK TAMÁS \\ Budapest XI. Hamzsabégi út 13. H-1117 \\ e-mail: xanthomelas@mailbox.hu
}

\begin{abstract}
HudÁk, T.: Investigation on the butterfly fauna of Székesfehérvár (Lepidoptera: Rhopalocera).
Abstract: The butterfly fauna of Székesfehérvár and the neighbouring plains, Mezőföld has not been wellknown until now, because only few lepidopterologists and collectors worked in the area and the number of publications was low. The author has been observing butterflies and recording data since the late 1980s and together with the data collected by Kálmán Szeöke the number of species ever recorded in Székesfehérvár is currently 101, of which 43 are protected by the law. The most significant species are the strictly protected Colias chrysotheme, Maculinea nausithous, which reaches its southeastern area border in Hungary in this area and the very rare mediterranean vagrant species, Lampides boeticus. The present-day occurrences of Parnassius mnemosyne, Zerynthia polyxena, Lycaena dispar rutilus, Maculinea teleius and Spialia orbifer are also worth mentioning.
\end{abstract}

Keywords, butterfly, protected area, occurrence, Hungary

\section{Bevezetés}

Székesfehérvár a Mezőföldön található, százezres megyeszékhely. Több földrajzi kistáj találkozásánál fekszik: a legújabb felosztás (DövÉNYI et al. 2009) szerint északról a Sörédihát és Móri-árok nyúlnak be a város területére, nyugatról a Sárrét lápos-mocsaras vidéke határolja, délen a Közép-Mezőföld löszös-homokos síkságát találjuk, míg keleten a Velencei-hegység, valamint a Velencei-tó és annak lápvidéke határolják a várost. Területe nagyrészt sík vidék, csak két ponton, északon Máriamajor környékén és keleten a Velenceihegység északi lejtőin éri el a 200 méteres tengerszintfeletti magasságot. Ennek ellenére a több, különböző felszínü és talajú kistáj változatos élővilág kialakulását tette lehetővé.

A város két országos jelentőségü természetvédelmi területtel rendelkezik: a Székesfehérvári Homokbánya TT teljes területe, illetve a Dinnyési Fertő TK kisebb része tartozik a városhoz. A helyi jelentőségü védett területek közül kiemelhető a Homokbánya TT-tel szerves egységet alkotó Sóstó TT, valamint a nemrég védettséget kapott Aszal-völgyi TT és Máriamajori-erdő TT. Több terület védetté nyilvánítása jelenleg is folyamatban van. A védetté nyilvánítások irányították rá a figyelmet többek között a környék lepkefaunájának kutatására.

Székesfehérvár lepkefaunájáról korábban nagyon kevés publikált adat állt a rendelkezésünkre. KovÁcs (1953) faunakatalógusában mindössze tíz nappali lepkefajt sorol fel Székesfehérvár helymegjelöléssel. Ezek közül kiemelhető a Maculinea arion, a Colias chrysotheme, Lycaena dispar és Cupido decoloratus. BÁLinT (1994) földrajzi régiókra osztva adott áttekintést hazánk nappali lepkéiről a Mezőfölddel kapcsolatban 
ezt írta: „A vidék nappali lepkefaunáját kevesen kutatták. Publikált faunalistát nem sikerült találnom."

A kevés számú kutató közül messze kiemelkedik Szeőke Kálmán, aki 1965 óta vizsgálja Székesfehérvár és környékének lepkéit. Kutatásait föleg a város nyugati részén végezte. Eredményeit még nem publikálta, de kéziratát rendelkezésemre bocsátotta. Részletes fajlistájából kiemelendő a Pieris ergane, Chazara briseis, Euphydryas maturna és Maculinea teleius előfordulása.

Petrich (2001) Velencei-tó és környékének lepkéiröl írt kiváló könyvében egy Székesfehérvárhoz tartozó lelőhelyet is felsorol, a Körakás-szurdokot (Császár-víz völgye), ahol 1972-ben és 1980-81-ben végzett néhány alkalommal nappali gyüjtést. Az elökerült fajok közül az akkor még gyakori Nymphalis urticae valamint a Coenonympha arcania méltó említésre.

BANIzs et al. (2010) Sóstóról írt könyvet, melyben többek között a Parnassius mnemosyne és a Lycaena dispar rutilus elöfordulása szerepelt.

Jelen közlemény célja egy természetvédelmi felhasználásra is alkalmas összegzés készítése a város területén eddig megfigyelt nappali lepkékről, élőhelyeikről, gyakoriságuk változásairól, amely remélhetőleg segítséget nyújt abban, hogy a jövőben nemcsak a város, hanem a Mezőföld lepkefaunája is jól feltárt legyen.

\section{Anyag és módszer}

A 80-as évek vége óta foglalkozom hosszabb-rövidebb szünetekkel a város lepkefaunájával, feljegyzett adataim 1987 óta vannak. Kezdetben nagyrészt a Sárpentelei-erdő és a Csúcsos-hegy területét jártam be, később a Sóstó, az Aszal-völgy és környéke, újabban a Császár-víz völgye és a Csalai-erdő váltak kutatásaim fő célpontjává.

Az elmúlt néhány évben szisztematikusan vizsgáltam a város értékesebb természeti területeit, a vegetációs időszakban havi rendszerességgel bejárva az élőhelyeket. A fajokat terepi megfigyeléssel és saját fotóim alapján azonosítottam. A nehezen határozható génuszok esetén (Colias, Polyommatus, Thymelicus) a határozás mindig fénykép alapján történt. A székesfehérvári lepkefauna vizsgálata során 12 lelöhelyen végeztem megfigyeléseket.

\section{Aszal-völgy, Rác-völgy}

A város északi határában, 2015 óta helyi védett területen két, egymásra meröleges irányú löszvölgy található. Az Aszal-völgy egy több kilométer hosszú patakvölgy, melynek felső végén igen értékes, védett növényekben gazdag száraz löszgyepek találhatók. Nagy mennyiségben nő rajtuk az Adonis vernalis, a Pulsatilla nigricans, az Iris pumila és a Vinca herbacea, de megtaláljuk a Prunus tenella bokrait, valamint ősszel néhány tő Sternbergia colchiciflora fajt is.

A Rác-völgy az Aszal-völgy végétöl északkelet felé halad. Alján rendszeresen kaszált, valamivel nedvesebb talajú, a völgy oldalában és északi szakaszán erősen cserjésedöerdősülő, gazdag flórájú terület, olyan a Mezőföldön ritkaságnak számító növényekkel, mint a Pulsatilla grandis, a Helleborus dumetorum, a Dictamnus albus, a Linum flavum, a Gentiana cruciata, a Ajuga laxmannii, a Phlomis tuberosa, a Aster amellus, a Sternbergia colchiciflora és a Orchis purpurea. 


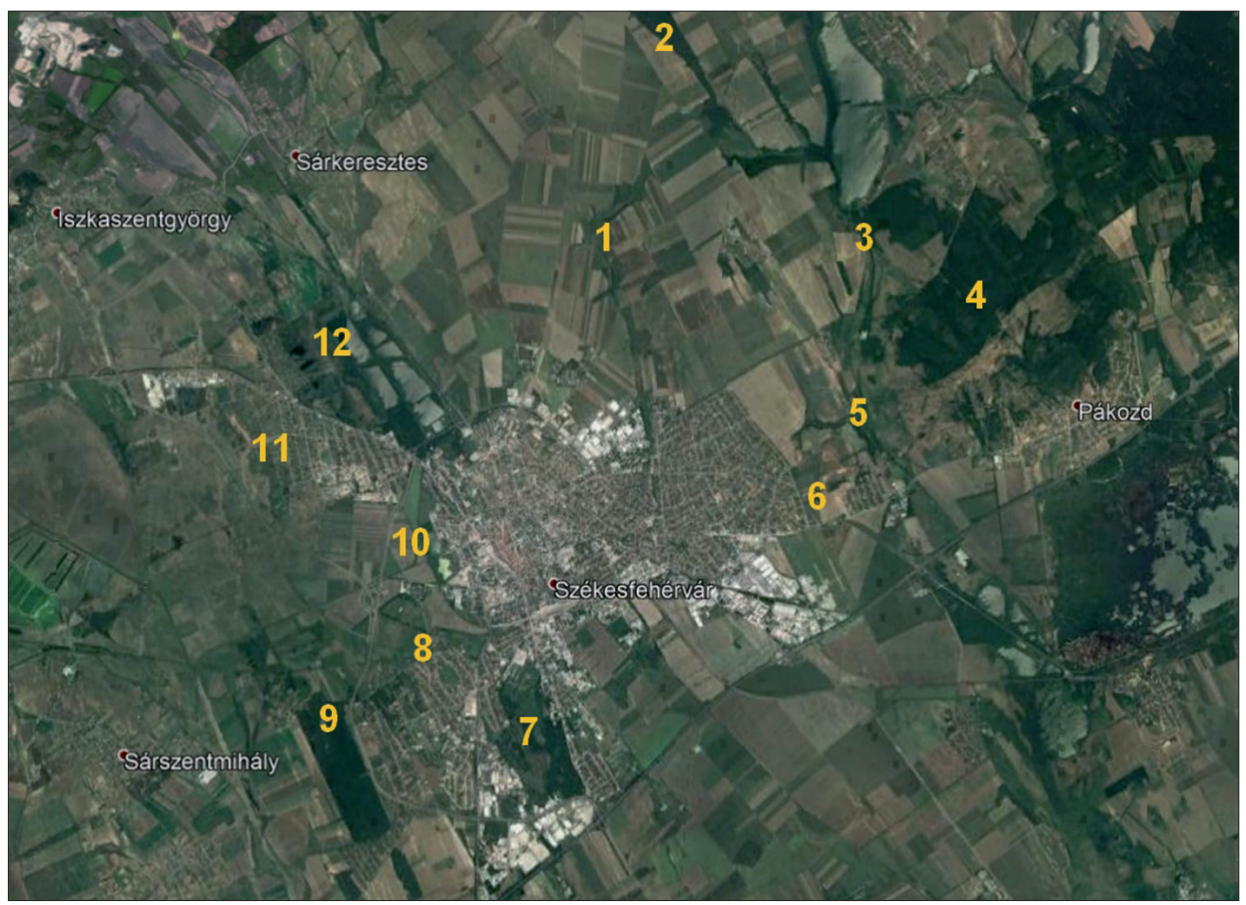

1. ábra: Mintavételi helyek Székesfehérvár környékén

1. Aszal-völgy, Rác-völgy; 2. Máriamajori-erdő; 3. Császár-víz völgy északi szakasz, Jézus-hegy, Malom-hegy; 4. Csalai-erdő; 5. Császár-víz völgy középső szakasz, Murvás-hegy; 6. Csúcsos-hegy, Jancsár; 7. Sóstó és Homokbánya TT.; 8. Alsóvárosi-rétek (Demkóhegy), Maroshegy; 9. Sárpentelei-erdő; 10. Gaja-patak, Palotavárosi-tavak; 11. Feketehegy; 12. Gólya-dủlö, Nyúl-dűlő

\section{Máriamajori-erdó}

A Máriamajori-erdő a Rác-völgytől még északabbra, félreeső helyen található a lakott területektől távol a város közigazgatási határának északi csücskében. Egyes részeit igen jó állapotú, zárt lösztölgyes borítja, melynek köszönhetően 2015-ben helyi védettséget kapott. Aljnövényzetében tavasszal tömeges a Helleborus dumetorum, de egy tisztásán az Adonis vernalis és a Phlomis tuberosa fajok is teremnek (Kovács 2017).

\section{Császár-víz völgy északi szakasz, Jézus-hegy, Malom-hegy}

A Császár-víz pataknak a Pátkai-víztározótól délre található szakasza tartozik a városhoz. A völgy székesfehérvári szakasza három részre osztható: északi szakasza a víztározó és Csalapuszta (811. sz. út) között halad és igen változatos, részben erdös, környékénél párásabb, hüvösebb klímájú terület (Körakás-szurdoknak is hívják), helyenként magaskórós, gyalogbodzás növényzettel, valamint délebbre jó állapotú, nedves kaszálórétekkel. A réteken Anacamptis morio, illetve néhány tö Sanguisorba officinalis terem (Kovács 2015a).

A patak keleti oldalán a Malom- vagy Kőrakás-hegy a másik kiemelkedő pont. Érdekessége hogy viszonylag nagy területét túlnyomó részben tölgyes borítja, kisebb nagyobb irtásokkal és akácos foltokkal, déli lejtője száraz, degradált gyep. 


\section{Csalai-erdö}

Pákozdtól északra, Csalapusztától keletre a Velencei-hegység északi lejtőjén találjuk a Csalai-erdőt. Dombvidéki jellegü terület, észak-déli irányú hegygerincek és völgyek tagolják, a gerinceket helyenként sziklakibúvások színesítik. Növénytakarójának túlnyomó része méhészeti céllal használt, ugyanakkor természetvédelmi szempontból teljesen értéktelen akácos, azonban a Kovács-berke nevü részen nagyobb kiterjedésü tölgyes foltok is megmaradtak, nyáron dús növényzetnek köszönhetően gazdag lepkefauna alakult ki.

\section{Császár-víz völgy középső szakasz, Murvás-hegy}

A Császár-víz középső szakaszát Csalapuszta és Kisfalud között találjuk. Bal partján Csalapusztától keletre horgásztavat létesítettek, tőle délre nagy kiterjedésü, száraz juhlegelő terül el. A patakot hosszan füzesek szegélyezik, jobb partján kaszálórétek és zártabb erdős részek váltogatják egymást, amelyekben Cephalantera damasonium is előfordul (Kovícs 2015b).

Kisfalud közelében egy meredek oldalú domb szegélyezi a völgyet, ez a Murvás-hegy. Tetején fiatal tölgyes nő, meredek keleti oldalát igen száraz gyep borítja.

\section{Csúcsos-hegy, Jancsár}

A 182 méter magas Csúcsos-hegy tetején az Aranybulla Emlékmüvel a város egyik népszerü kirándulóhelye. Korábban természetes jellegü száraz gyep borította, ma már egyre inkább részben parkosított, részben spontán cserjésedő területté válik nagyrészt ültetett növényzettel, nyugati lejtöjén cserszömörcével, a keletin akácossal. Igen meleg mikroklímájának köszönhetően mindig is ez volt az a terület, ahol kora tavasszal az első áttelelt lepkéket meg lehetett figyelni. A hegy és a Császár-víz völgye között a Jancsár nevü terület helyezkedik el, ahol degradált száraz gyepeket, akácost, müködő és felhagyott murvabányákat találunk. A város közelsége miatt igen rossz állapotúak az élöhelyek: szemétlerakás, murvabányászat és az ehhez kötődő teherautóforgalom tette tönkre őket. Néhány tő Pulsatilla nigricans és Adonis vernalis máig túlél, sajnos a Iris pumila már kipusztult (BANIZS 2008).

\section{Sóstó és Homokbánya TT}

A város déli oldalán találhatók, egymással összefüggő, orchidea fajokban gazdag, védett területek. Az egykori homokbánya és az elnádasodott Sóstó környékén változatos élőhelyeket találunk: láp és mocsárrétek, pusztagyepek, homoki gyepek, kisebb-nagyobb erdőfoltok. Szép számmal előforduló orhideái az Orchis militaris, az Anacamptis laxiflora, az Anacamptis coriophora és az Epipactis palustris, de megtalálhatjuk a fokozottan védett Ophrys sphegodes, Cephalantera damasonium, C. longifolia, Orchis morio, Listera ovata és az Epipactis helleborine fajokat is. Ezeken kívül Iris arenaria, Blackstonia acuminata, Dianthus giganteiformis, Prunus tenella növelik a terület értékét (BANIZs 2008), amely mostanra teljesen körbeépült lakó és ipari területekkel, föutakkal.

Megfigyeléseim szerint 2000 után a Sóstó és a környező természetvédelmi terület vízutánpótlás hiányában sajnálatos módon egyre jobban kiszáradt, a tavon a nyílt vízfelület, a többi részen a talajnedvesség drámai mértékben csökkent, a láp és mocsárrétek átalakultak. Ennek következményeként a nedvességigényesebb fajok közül eltünt a Dactylorhiza incarnata, a Parnassia palustris a 80-as évek óta nem kerül elő.

\section{Alsóvárosi-rétek (Demkóhegy), Maroshegy}

Székesfehérvárt nyugatról a Sárrét határolja. A nedves, lápos rétek Maroshegytől északra egészen beékelődnek a város területébe. A veszprémi és a komáromi vasút közötti városrész a Demkóhegy, az azt három oldalról körülvevő gyepes területet pedig Alsóvárosi-réteknek nevezik. 


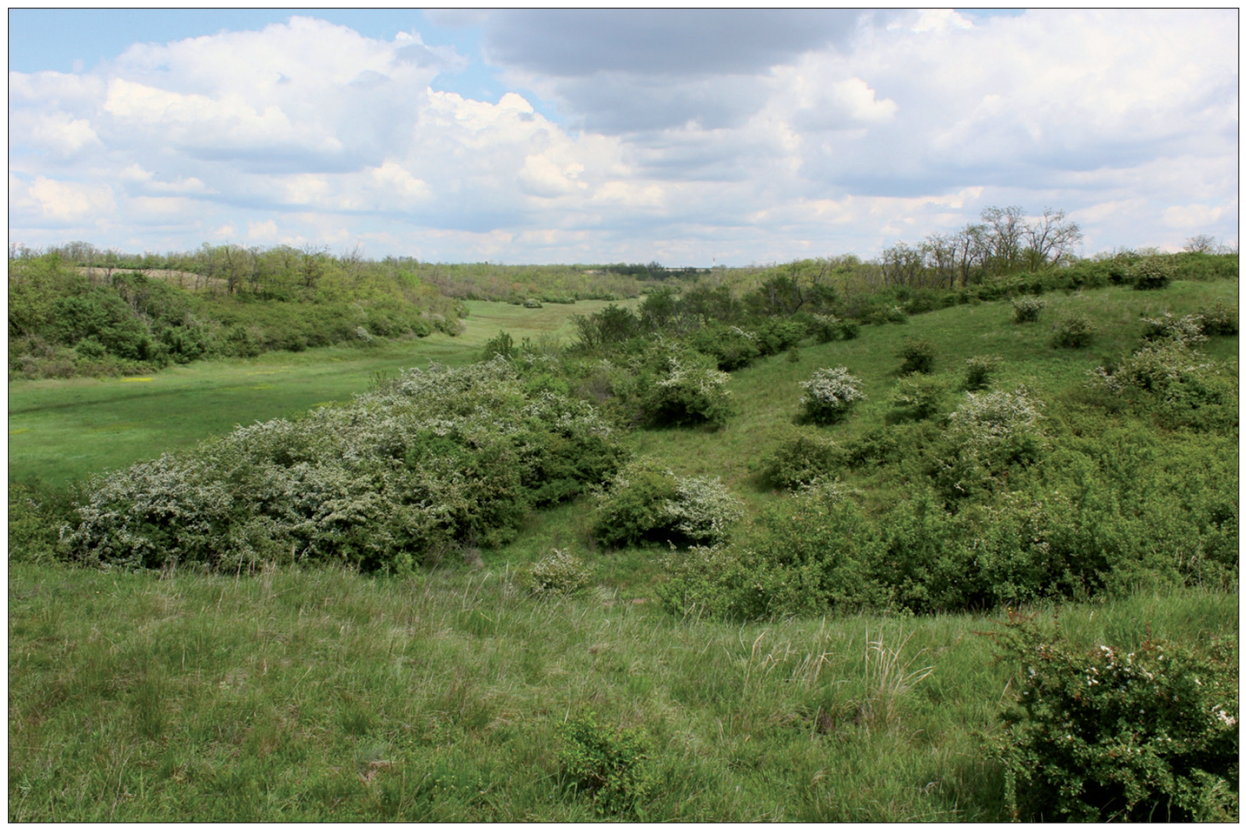

1. ábra: Az Aszal-völgy, balra a háttérben a Rác-völgy

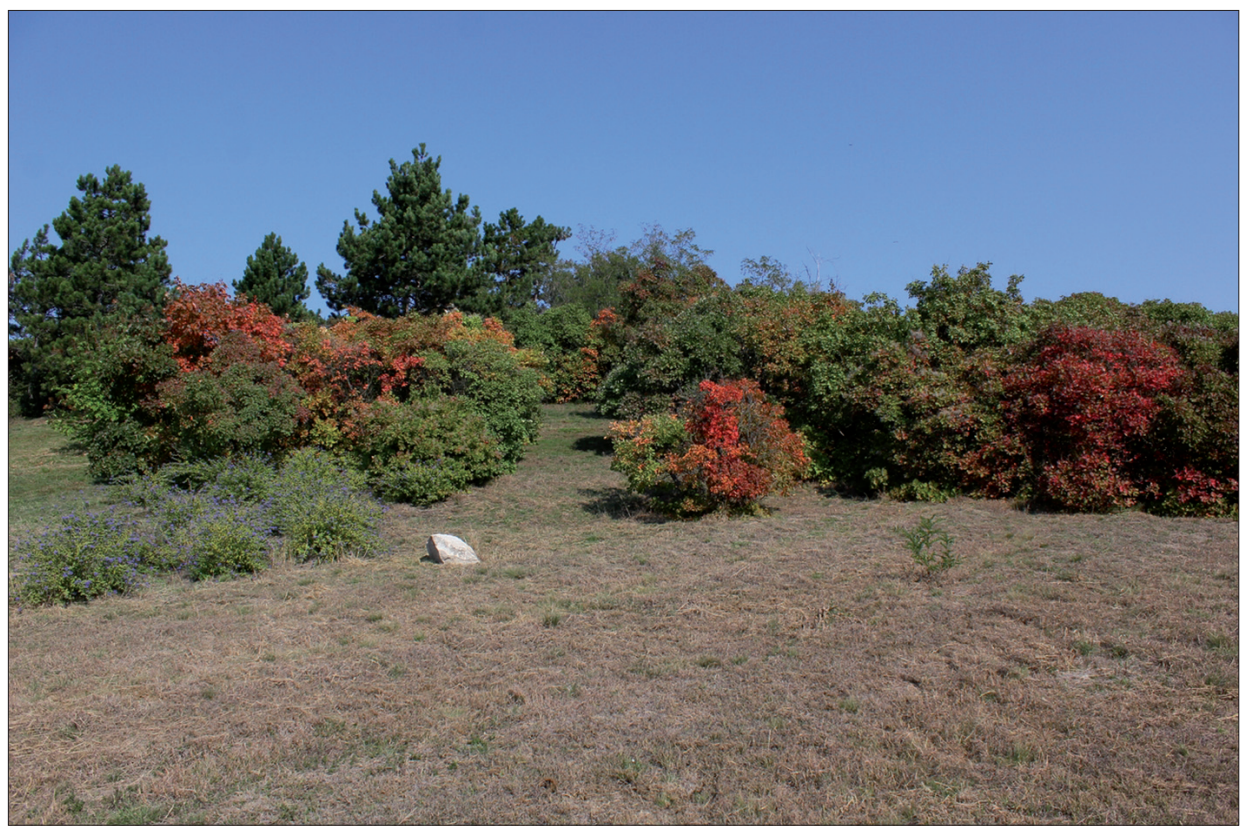

2. ábra: Csúcsos-hegy ősszel 


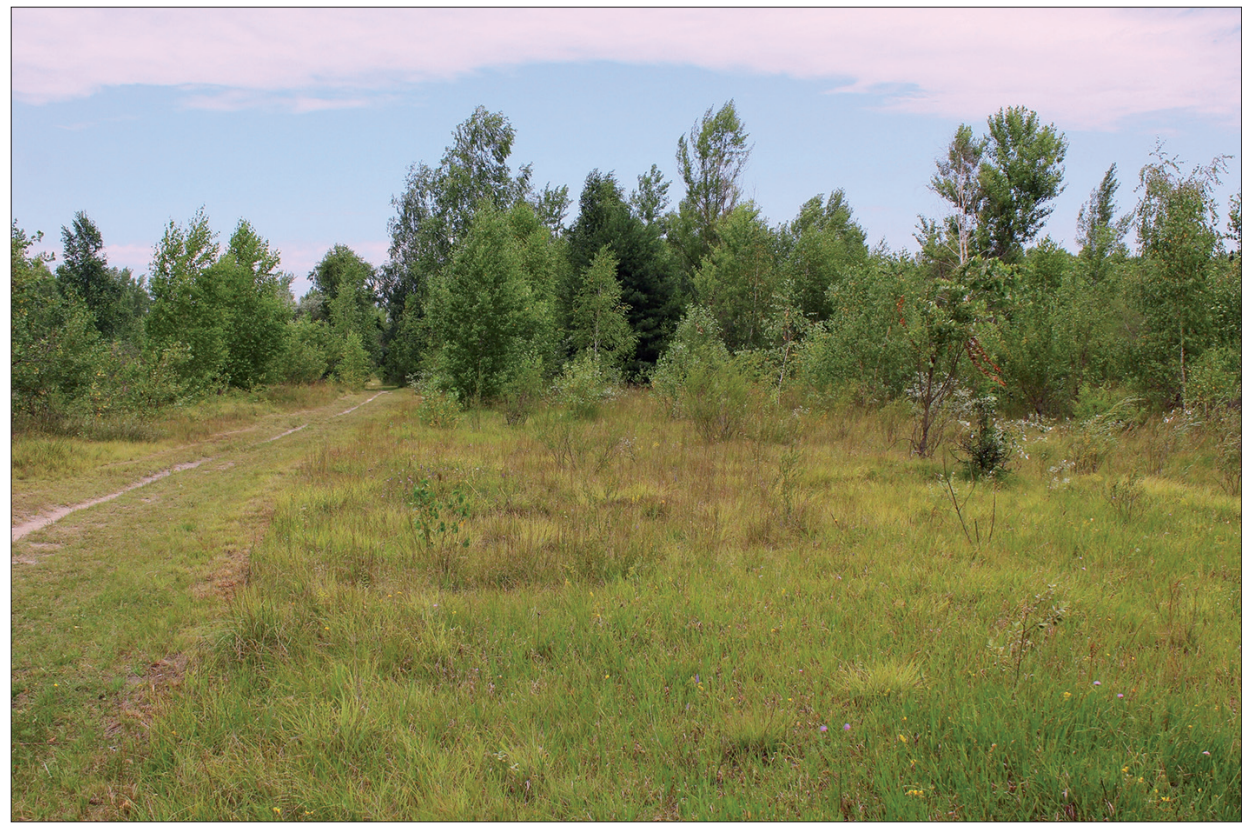

3. ábra: A Sóstó Természetvédelmi Terület

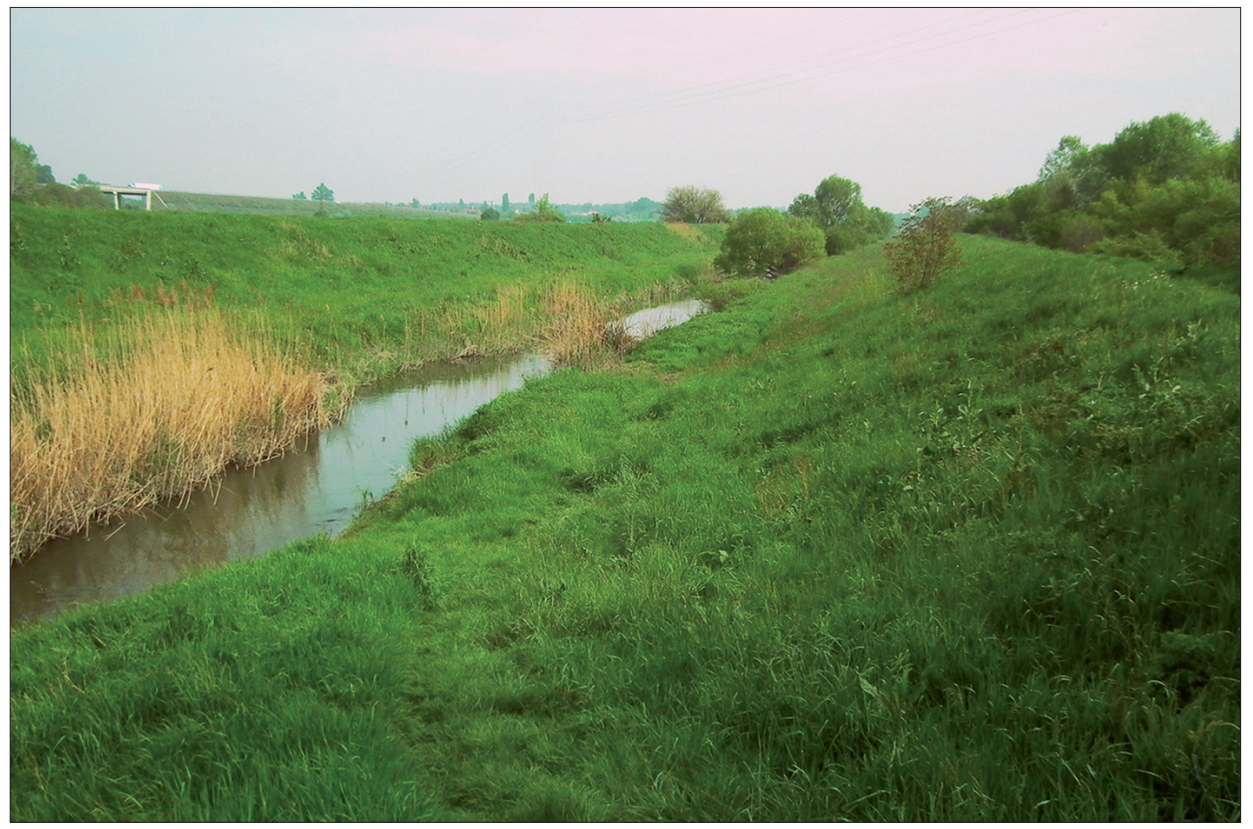

4. ábra: A Gaja-patak Palotaváros melletti szakasza 
Az itt található gyepek helyenként igen értékes növényzetet rejtenek: védett fajaik a Centaurea sadleriana, a Stipa pennata, az Anacamptis morio. Egy hajdani kubikgödör alján a Sóstó TT-hez hasonló homoki gyepben szép számmal nő az Anacamptis coriophora és megtalálható az Orchis militaris is. A veszprémi vasút mentén nedves kaszálórétek terülnek el, melyeken többfelé tömeges a Sanguisorba officinalis.

A veszprémi vasúttól délre találjuk Maroshegyet, amely a város zöldterületben leginkább gazdag része (BANIzs et al. 2007). A mai napig maradtak fenn beépítetlen területek, ahol erdőfoltok, láprétek és mocsaras területek tarkítják a tájat. Az egyik telepített tölgyes a Cephalantera damasonium országosan is az egyik leggazdagabb állományát rejti az Orchis militaris társaságában.

\section{Sárpentelei-erdö}

Bár a Sárpentelei-erdőnek közigazgatási szempontból csak igen kis része tartozik Székesfehérvárhoz, közeli fekvése, népszerü kirándulóhely és sportközpont mivolta miatt a város lakói mégis magukénak érzik. A nagyrészt tölgy, fenyő és akác fafajokból álló erdő déli része régebben is zárt, nappali lepkék szempontjából szegényes területnek számított, északi része azonban a nyolcvanas, kilencvenes években még napos, nyíltabb lombkoronájú terület volt. A lepkékben leginkább gazdag terület a mélyebben fekvő, nedvesebb északi, északkeleti harmada volt, ma már ez a rész is zárt erdővé alakult, ezért lombfakadás után lepkékkel leginkább csak az erdőszegélyeken, irtásokon és az erdőt északról határoló nedves réteken találkozhatunk.

\section{Gaja-patak, Palotavárosi-tavak}

A Gaja-patak a Császár-víz mellett Székesfehérvár legjelentősebb természetes vízfolyása. A Móri-árok felöl érkezve a Palotavárosi lakótelep nyugati szegélyén halad és ökológiai folyosóként szolgál a sok beépített és müvelt terület között.

\section{Feketehegy}

A Feketehegy városrész Székesfehérvár északnyugati végén található. Ma már beépített, részben lakó, részben hobbikertes övezet, ahol a természetes növényzet csak kisebb foltokban és a városrész peremén maradt meg.

\section{Gólya-dülö, Nyúl-dülö}

A dülők Szárazrét városrészhez tartoznak, a régi 8-as úttól északkeletre a komáromi vasút két oldalán húzódóan terülnek el. A Nyúl-dűlő keleti oldalán folyik a Gaja-patak és itt találjuk a Vörösmarty-halastavakat. A dűlő északi része már a Móri-árok területéhez tartozik.

Növényzetét tekintve nagyrészt degradált bokros-erdös területek, ahol helyenként Prunus tenella él (BANIzs 2008), azonban a halastavak északi, északnyugati szegélyében lápos, vérfüves gyepfoltok maradtak fenn, védett növényük az Iris spuria. 


\section{Eredmények}

Székesfehérváron az eddig kimutatott Rhopalocera fajok száma: 101.

A megfigyelt fajok listájában a lelöhelyeket számmal jelöltük: 1. Aszal-völgy, Rácvölgy; 2. Máriamajori-erdő; 3. Császár-víz völgy észak, Jézus-hegy, Malom-hegy; 4. Csalai-erdő, Zsellér-legelö; 5. Császár-víz völgy közép, Murvás-hegy; 6. Csúcsos-hegy, Jancsár; 7. Sóstó és Homokbánya TT.; 8. Alsóvárosi-rétek, Maroshegy; 9. Sárpenteleierdő; 10. Gaja-patak, Palotavárosi-tavak; 11. Feketehegy; 12. Szárazrét: Gólya-dülö, Nyúl-dűlő

A megfigyelö vagy adatközlö neve: SZK - Szeőke Kálmán, PK - Petrich Károly, BK Banizs Károly et al., KG - Kovács Gergely, HT - Hudák Tamás

A 2000 utáni megfigyelési dátumokat vastag betűvel jelöltük. A Colias alfacariensis és Colias hyale fajok sok esetben fénykép alapján sem különböztethetőek meg biztosan, ezért a két faj megfigyeléseimben együtt szerepel, azzal a megjegyzéssel, hogy az alfacariensis jóval gyakoribbnak tünik rokonánál.

\section{A megfigyelt fajok listája}

\section{Hesperiidae}

Erynnis tages (Linnaeus, 1758) SZK: 7, 8, 9, 12; PK: 3; HT: 3, 4, 8;

Carcharodus alceae (Esper, 1780) SZK: 7, 8, 9, 12; PK: 3; HT: 3, 8, 9

Carcharodus floccifera (Zeller, 1847) SZK: 7, 8, 9, 12; HT: 3, 9

Pyrgus malvae (Linnaeus, 1758) SZK: 7, 8, 9, 12; PK: 3; BK: 7; HT: 1, 3, 4, 6, 8, 9

Pyrgus serratulae (Rambur, 1839) SZK: 9, 12

Pyrgus armoricanus (Oberthür, 1910) SZK: 7, 8, 9, 12; HT: 1,5

Spialia orbifer (Hübner, 1823) HT: 4

Carterocephalus palaemon (Pallas, 1771) SZK: 9

Hesperia comma (Linnaeus, 1758) SZK: 7, 8, 9, 12; HT: 1, 3;

Ochlodes sylvanus (Esper, 1779) SZK: 7, 8, 9, 12; HT: 1, 3, 4, 8, 9, 12

Thymelicus lineola (Ochsenheimer, 1808) SZK: 7, 8, 9, 12; PK: 3; HT: 3, 4, 5, 8

Thymelicus sylvestris (Poda, 1761) SZK: 7, 9; PK: 3; HT: 3

\section{Papilionidae}

Papilio machaon (Linnaeus, 1758) SZK: 7, 8, 9, 12; BK: 7; KG: Pénzverő-völgy; HT: 2, 3, 6, 7, 8, 9, 10

Iphiclides podalirius (Linnaeus, 1758) SZK: 7, 8, 9, 12; BK: 7; HT: 1, 2, 3, 4, 5, $6,8,9,10,11$

Zerynthia polyxena (Denis \& Schiffermüller, 1775) SZK: 12; HT: 1, 3, 10

Parnassius mnemosyne (Linnaeus, 1758) BK: 7; HT: 3, 4

\section{Pieridae}

Pieris brassicae (Linnaeus, 1758) SZK: 7, 8, 9, 12; HT: 2, 3, 6, 8, 9

Pieris ergane (Geyer, 1828) SZK: 8, 12

Pieris napi (Linnaeus, 1758) SZK: 7, 8, 9, 12; PK: 3; HT: 1, 2, 3, 4, 5, 6, 7, 9, 10, 12

Pieris rapae (Linnaeus, 1758) SZK: 7, 8, 9, 12; PK: 3; HT: 1, 2, 3, 4, 5, 6, 7, 8 ,

9, 10, 11, 12

Leptidea sinapis (Linnaeus, 1758) SZK: 7, 8, 9, 12; PK: 3; HT: 1, 2, 3, 4, 5, 6, 7, 9, 10, 12 


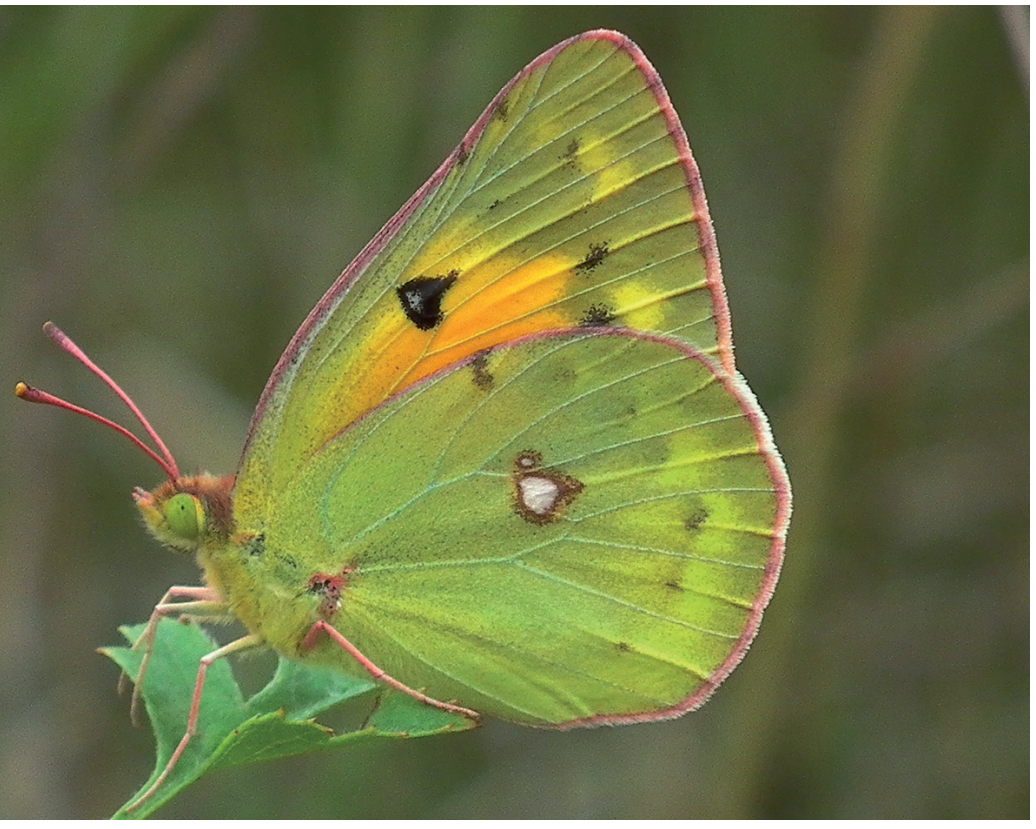

5. ábra: Colias chrysotheme az Aszal-völgyben

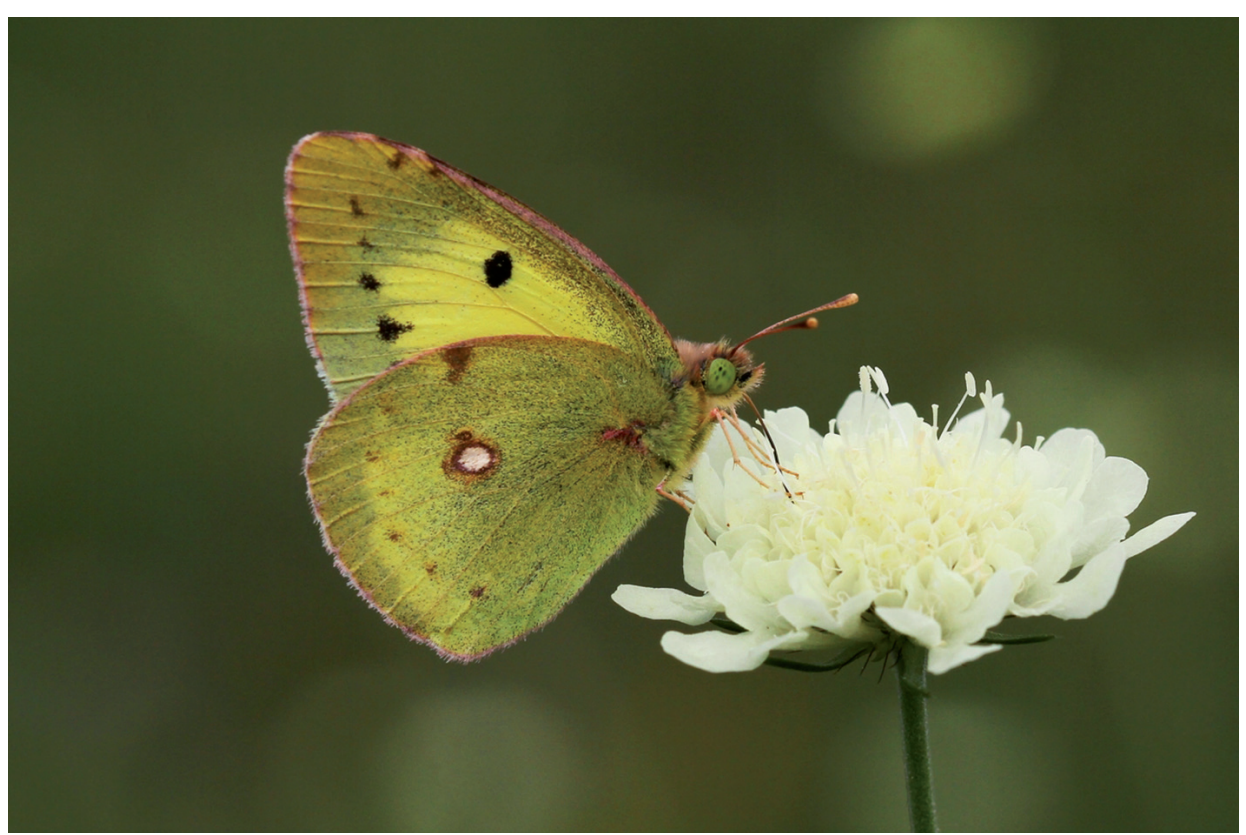

6. ábra: Colias erate a Rác-völgyben 


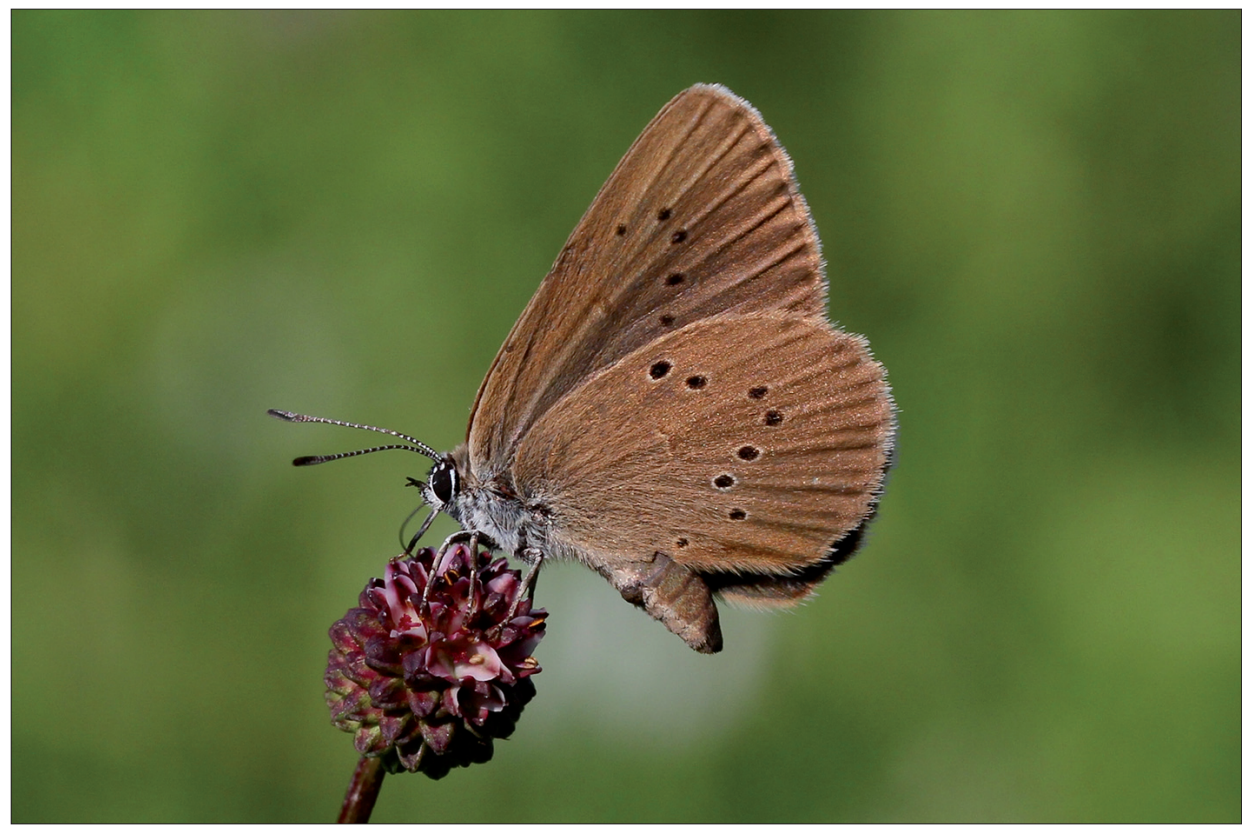

7. ábra: Maculinea nausithous az Alsóvárosi-réteken

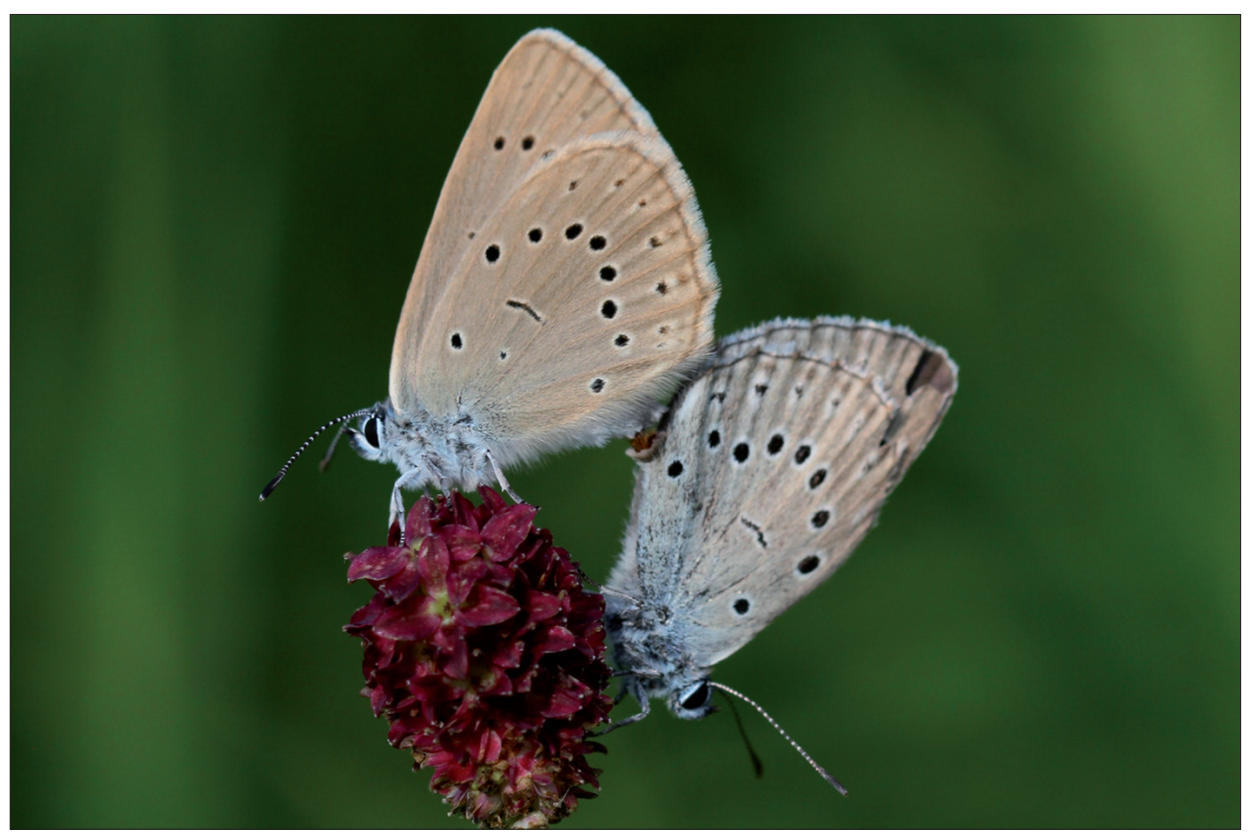

8. ábra: Maculinea teleius a Nyúl-dülőben 
Leptidea reali (Reissinger, 1989) SZK: 9, 12 Aporia crataegi (Linnaeus, 1758) SZK: 7, 8, 9, 12; HT: 4, 5

Gonepteryx rhamni (Linnaeus, 1758) SZK: 7, 8, 9, 12; HT: 1, 2, 3, 4, 5, 6, 7, 8, 9, 10, 12 Anthocaris cardamines (Linnaeus, 1758) SZK: 7, 8, 9, 12; BK: 7; HT: 1, 3, 4, 6, 7, 8, 9, 10 Pontia edusa (Fabricius, 1777) SZK: 7, 8, 9, 12; PK: 3; BK: 7; HT: 1, 3, 5, 6, 7, 8, 10 Colias alfacariensis (Ribbe, 1905) SZK: 7, 8, 9, 12

C. alfacariensis + hyale) HT: 1, 3, 4, 5, 6, 7, 8, 9, 10, 11

Colias hyale (Linnaeus, 1758) SZK: 7, 8, 9, 12

Colias chrysotheme (Esper, 1781) HT: 1, 6, 11

Colias croceus (Geoffroy in Fourcroy, 1785) SZK: 7, 8, 9, 12; HT: 1, 3, 5, 6, 8, 9, 10, 11, 12 Coilas erate (Esper, 1805) SZK: 7, 8, 9, 12; HT: 1, 6;

\section{Lycaenidae}

Satyrium acaciae (Fabricius, 1787) SZK: 7, 8, 9; HT: 3

Satyrium ilicis (Esper, 1779) SZK: 7, 8, 9, 12; HT: 4

Satyrium pruni (Linnaeus, 1758) SZK: 8; HT: 1, 3, 4, 5, 12

Satyrium spini (Denis \& Schiffermüller, 1775) SZK: 7, 8, 9, 12; HT: 2, 3, 7

Satyrium w-album (Knoch, 1782) SZK: 7, 9; HT: 3

Neozephyrus quercus (Linnaeus, 1758) SZK: 7, 9

Thecla betulae (Linnaeus, 1758) SZK: 8, 9, 12

Callophrys rubi (Linnaeus, 1758) SZK: 7, 8, 9, 12; KG: 1; HT: 4, 6

Lycaena dispar rutilus (Werneburg, 1864) SZK: 7, 8, 9, 12; BK: 7; KG: Új-Gáti

parrag; HT: 1, 3, 6, 8, 9, 10, 12

Lycaena phlaeas (Linnaeus, 1761) SZK: 7, 8, 9, 12; HT: 1, 3, 4, 5, 6

Lycaena thersamon (Esper, 1784) SZK: 7, 8, 9, 12; BK: 7; HT: 1, 3, 6, 11, 12

Lycaena tityrus (Poda, 1761) SZK: 7, 8, 9, 12; HT: 1, 3, 4, 5, 6, 8

Lampides boeticus (Linnaeus, 1767) HT: 6

Cupido alcetas (Hoffmannsegg, 1804) SZK: 7, 9

Cupido argiades (Pallas, 1771) SZK: 7, 8, 9, 12; HT: 5, 8, 10, 11, 12

Cupido decolorata (Staudinger, 1886) SZK: 7, 8, 9, 12

Cupido minimus (Fuessly, 1775) SZK: 7, 8, 9, 12; HT: 1, 3, 4, 5, 6

Celastrina argiolus (Linnaeus, 1758) SZK: 7, 8, 9, 12; HT: 1, 2, 3, 4, 5, 6, 7, 8, 9, 10, 12

Pseudophilotes vicrama (Hemming, 1929) SZK: 8, 9, 12

Plebeius argus (Linnaeus, 1758) SZK: 7, 8, 9, 12; BK: 7; HT: 1, 3, 4, 5, 6, 7, 8, 9, 11, 12

Plebeius argyrognomon (Bergstrasser, 1779) SZK: 7, 8, 9, 12; HT: 1, 3, 4, 5, 11, 12

Glaucopsyche alexis (Poda, 1761) SZK: 7, 9, 12; HT: 7

Maculinea arion (Linnaeus, 1758) Székesfehérvár (KOVÁCS L. 1953)

Maculinea nausithous (Bergstrasser, 1779) HT: 8, 10, 11, 12

Maculinea teleius (Begrstrasser, 1779) SZK: 8, 9, 12; KG: 3; HT: 8, 10, 11, 12

Cyaniris semiargus (Rottemburg, 1775) SZK: 7, 9, 12

Polyommatus bellargus (Rottemburg, 1775) SZK: 7, 8, 9, 12; HT: 1, 3, 6, 7, 8, 11

Polyommatus coridon (Poda, 1761) SZK: 8, 9, 12; BK: 7; HT: 1, 3, 6, 7, 11

Polyommatus dorylas (Denis \& Schiffermüller, 1775) SZK: 8

Polyommatus icarus ((Rottemburg, 1775) SZK: 7, 8, 9, 12; HT: 1, 3, 4, 5, 6, 7, 8, 9, 11, 12

Polyommatus thersites (Cantener, 1835) SZK: 7, 8, 9, 12

Aricia agestis (Denis \& Schiffermüller, 1775) SZK: 7, 8, 9, 12; HT: 1, 2, 3, 4, 5, 6, 7, 10, 11

\section{Riodinidae}

Hamearis lucina (Linnaeus, 1758) HT: 3, 4 


\section{Nymphalidae}

Libythea celtis (Laicharting in Fuessly, 1807) SZK: 9; HT: 2, 4, 5, 6, 8, 9

Boloria dia (Linnaeus, 1758) SZK: 7, 8, 9, 12; HT: 1, 3, 4, 5, 6, 9, 10, 11

Brenthis daphne (Denis \& Schiffermüller, 1775) HT: 3, 4

Brenthis hecate (Denis \& Schiffermüller, 1775) SZK: 8, 9; HT: 1

Issoria lathonia (Linnaeus, 1758) SZK: 7, 8, 9, 12; HT: 1, 2, 3, 4, 5, 6, 7, 8, 9, 11, 12 Argynnis aglaja (Linnaeus, 1758) HT: 9

Argynnis pandora (Denis \& Schiffermüller, 1775) SZK: 7, 9; BK: 7; HT: 2, 3, 4, 5, 7, 9 Argynnis paphia (Linnaeus, 1758) SZK: 7, 9; BK: 7; HT: 1, 2, 3, 4, 5, 6, 7, 8, 9, 12

Euphydryas maturna (Linnaeus, 1758) SZK: 9; HT: 9

Melitaea athalia (Rottemburg, 1775) SZK: 7, 9; HT: 9

Melitaea cinxia (Linnaeus, 1758) SZK: 7, 8, 9, 12; HT: 1, 5, 8

Melitaea phoebe (Denis \& Schiffermüller, 1775) SZK: 7, 8, 9, 12; PK: 3; BK: 7;

HT: 1, 3, 4, 5, 6, 7, 8, 9, 11, 12

Melitaea trivia (Denis \& Schiffermüller, 1775) HT: 1, 3, 4, 11

Apatura ilia (Denis \& Schiffermüller, 1775) SZK: 7, 9, 12; HT: 1, 2, 3, 4, 5, 6, 8, 9

Araschnia levana (Linnaeus, 1758) SZK: 7, 8, 9, 12; BK: 7; HT: 1, 2, 3, 4, 5, 6, 8, 9, 11, 12

Nymphalis c-album (Linnaeus, 1758) SZK: 7, 8, 9, 12; BK: 7; HT: 1, 2, 3, 4, 5, 6, 7, 9, 10, 12

Nymphalis antiopa (Linnaeus, 1758) SZK: 7, 9; HT: 7

Nymphalis io (Linnaeus, 1758) SZK: 7, 8, 9, 12; BK: 7; HT: 1, 2, 3, 4, 5, 6, 7, 9, 10, 11, 12 Nymphalis polychloros (Linnaeus, 1758) SZK: 7, 9; HT: 1, 4, 5, 6, Vadmezö-dülö

Nymphalis urticae (Linnaeus, 1758) SZK: 7, 8, 9, 12; PK: 3; HT: 6, 9, 12

Vanessa atalanta (Linnaeus, 1758) SZK: 7, 8, 9, 12; BK: 7; HT: 1, 2, 3, 4, 5, 6, 7, 8, 9. 10, 12

Vanessa cardui (Linnaeus, 1758) SZK: 7, 8, 9, 12; BK: 7; HT: 1, 2, 3, 4, 5, 6, 7, 8, 9. 11, 12 Coenonympha arcania (Linnaeus, 1758) PK: 3; HT: 3, 4, 5, 12

Coenonympha glycerion (Borkhausen, 1788) SZK: 7, 8, 9, 12; HT: 1, 3, 4, 5, 6, 7, 9, 11

Coenonympha pamphilus (Linnaeus, 1758) SZK: 7, 8, 9, 12; HT: 1, 3, 4, 5, 6, 7, 8,

9, 10, 11, 12

Maniola jurtina (Linnaeus, 1758) SZK: 7, 8, 9, 12; PK: 3; HT: 1, 2, 3, 4, 5, 6, 7, 8, 9, 10, 11, 12

Lasiommata maera (Linnaeus, 1758) SZK: 7, 8, 9, 12; BK: 7; HT: 2, 3, 4, 6, 7, 9, 12 Lasiommata megera (Linnaeus, 1767) SZK: 7, 8, 9, 12; HT: 1, 3, 4, 5, 6, 7, 8, 9, 10 Pararge aegeria tircis (Godart, 1821) SZK: 7, 8, 9, 12; BK: 7; HT: 1, 2, 3, 4, 5, 7, 9, 12

Aphantopus hyperanthus (Linnaeus, 1758) SZK: 7, 8, 9, 12; HT: 1, 3, 4, 7, 9

Minois dryas (Scopoli, 1763) SZK: 7, 9; HT: 1, 2, 3, 4, 5, 6, 7, 8, 9, 11, 12

Chazara briseis (Linnaeus, 1758) SZK: 9, 12

Brintesia circe (Linnaeus, 1758) SZK: 9, 12; HT: 1, 3, 4, 5, 6, 7, 9, 11, 12

Hipparchia fagi (Scopoli, 1763) SZK: 9, 12; HT: 3, 4, 6

Hipparchia semele (Linnaeus, 1758) HT: 1, 4, 5, 6

Arethusana arethusa (Denis \& Schiffermüller, 1775) SZK: 8, 9, 12; PK: 3; HT: 1, 3, $\mathbf{4}, \mathbf{5}, \mathbf{6}, 7,12$

Melanargia galathea (Linnaeus, 1758 SZK: 7, 8, 9, 12; BK: 7; HT: 1, 2, 3, 4, 5, 6, 7, 9, 11, 12 


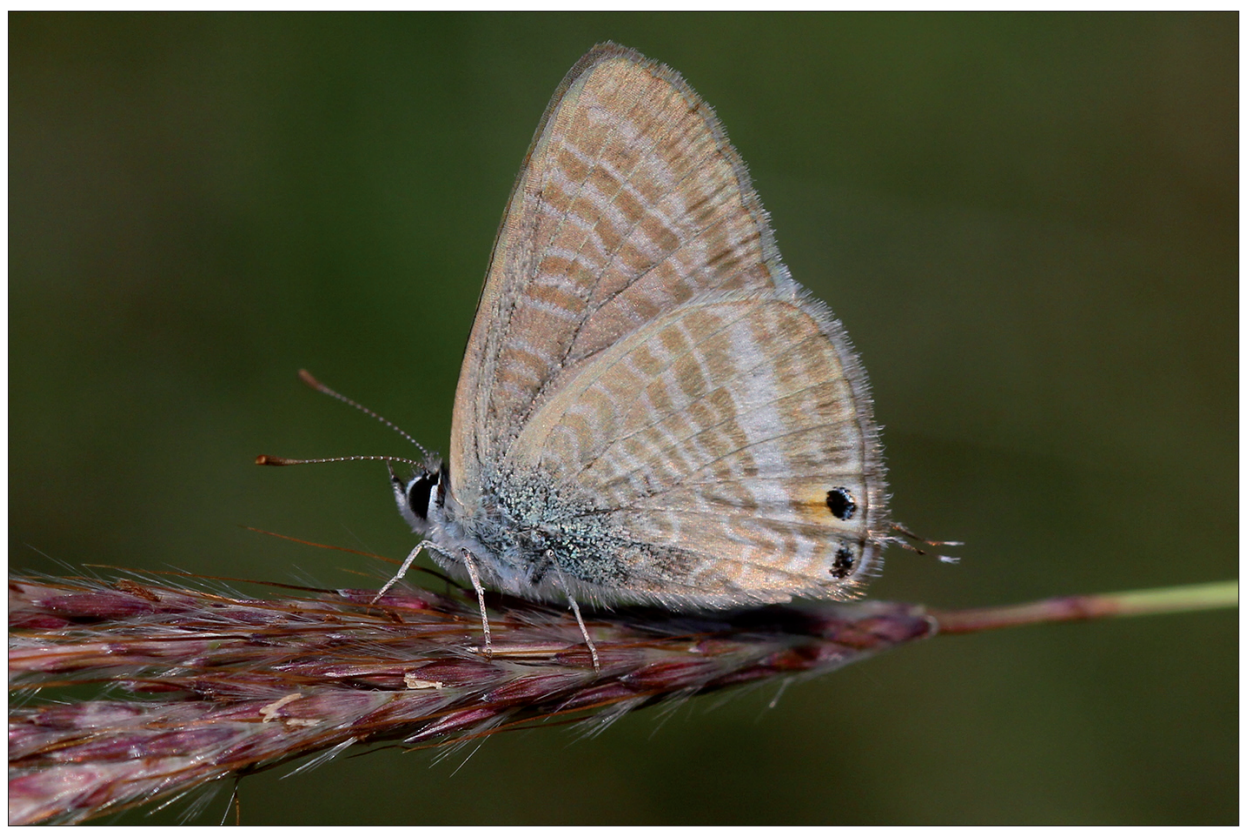

9. ábra: Lampides boeticus a Csúcsos-hegyen

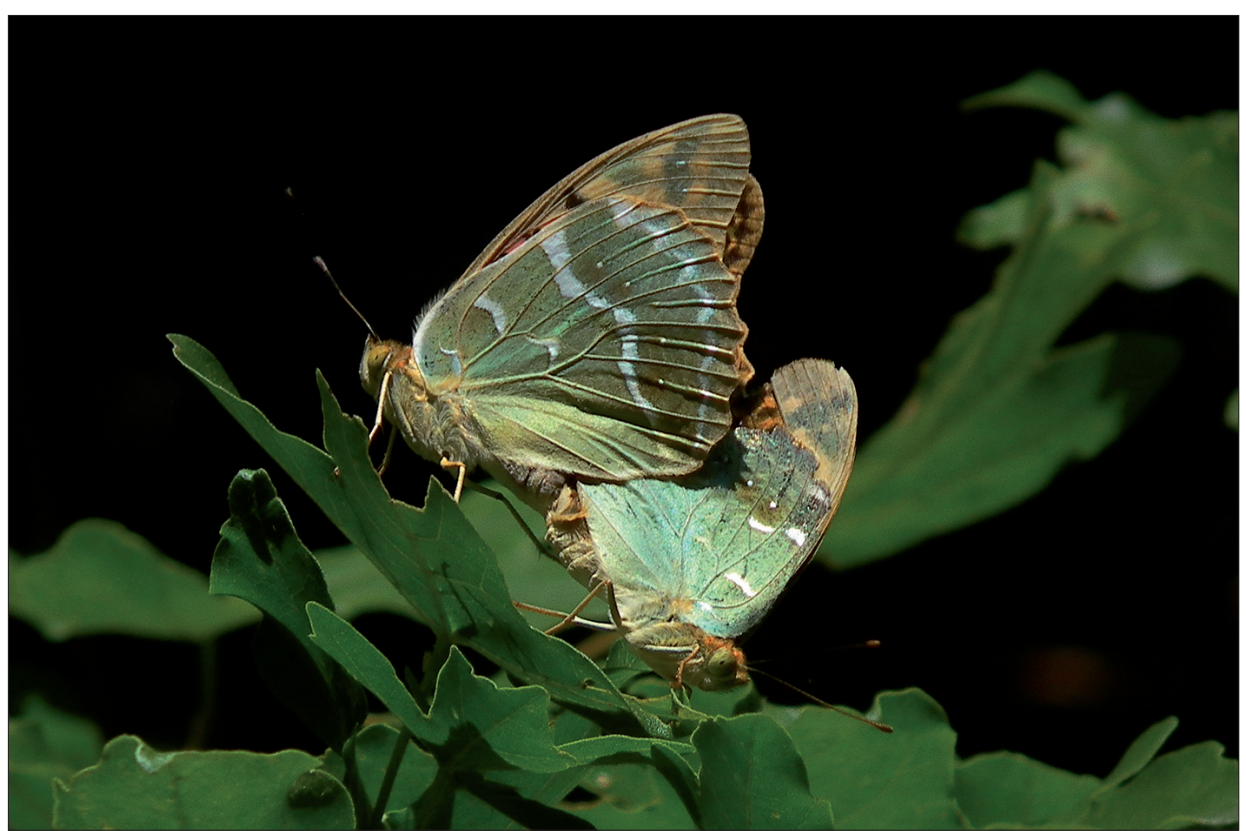

10. ábra: Argynnis pandora a Sóstó Természetvédelmi Területen 
Székesfehérváron eddig 101 nappali lepkefaj előfordulása bizonyított, amelyek közül körülbelül 75 napjainkban is rendszeresen megtalálható. A védett fajok száma 43.

A megtalált taxonok közül kiemelkedik a fokozottan védett Colias chrysotheme populációja, a Maculinea nausithous jelenleg itt éri el hazánkban elterjedésének keleti határát, a Lampides boeticus pedig országosan is igen ritka vándorlepkeként jelentős. Említésre méltók még a Parnassius mnemosyne, Zerynthia polyxena, Lycaena dispar rutilus, Maculinea teleius és a Spialia orbifer fajok tenyészése.

Összességében elmondható, hogy a város közvetlen környékének nappali lepkefaunája jól kikutatott, újabb fajok előfordulása leginkább jövőbeni terjedési tendenciák következményeként várható.

\section{A vizsgált élőhelyek nappali lepke faunájának jellemzése}

A Székesfehérvár környéki vizsgált mintavételi helyek nappali lepke közösségéről a jellemzö karakter fajok alapján külön jellemzést adok.

\section{Aszal-völgy, Rác-völgy}

Ezen a mintavételi helyen a lepkék közül legnagyobb érték a fokozottan védett Colias chrysotheme stabil populációja, amely mindkét völgyben megfigyelhetö, de megtaláljuk hazánkban elöforduló összes többi Colias fajt is (Colias erate, C. alfacariensis, C hyale).

Az Aszal-völgy kevésbé fajgazdag: jellemző fajai a Polyommatus bellargus, $P$. coridon. Júniusban óriási tömegben repül a Melanargia galathea. Eddig csak egyetlen példányban bukkant fel 2013-ban a Hipparchia semele, Kovács Gergely (szóbeli közlés) a Callophrys rubi előfordulását közölte. Az Apatura ilia atipikus lelöhelyen való felbukkanása a két völgy között elhelyezkedő füzfa-legeteknek köszönhető.

A Rác-völgyi gyepben a Zerynthia polyxena, és négy Lycaena faj, a Lycaena tityrus, L. phlaeas, L. thersamon, L. dispar, a Polyommatus coridon, a Plebejus argyrognomon, a Melitaea cinxia és a Arethusana arethusa a leginkább figyelemre méltó fajok. Az északi, kevésbé nyílt növényzetű rész egyik tisztásán bukkant fel 2015-ben a Brenthis hecate valamint a Satyrium pruni egy-egy példánya. Ezen a szakaszon már a Nymphalidae család fajai dominálnak, különösen gyakori a Araschnia levana, de a Nymphalis polychloros is rendszeresen megfigyelhetö.

\section{Máriamajori-erdö}

Az erdőben igen gyakori az Argynnis paphia, de elöfordul az A. pandora és az Apatura ilia is. Az erdőszegélyen gyakran látható a Libythea celtis, 2015 nyarán tömeges volt a Vanessa cardui, a Nymphalis io, a Araschnia levana és a Gonepteryx rhamni. 2017 júliusában a Satyrium spini meglepően nagyarányú rajzását tapasztaltam az északi erdőszegély gyalogbodza virágain.

\section{Császár-víz völgy északi szakasz, Jézus-hegy, Malom-hegy}

A lepkék közül kiemelendő a város nyugati oldalán sokkal gyakoribb Maculinea teleius, melynek Kovács Gergely találta meg néhány példányát 2015 augusztusában.

A kaszálón elöfordul a Székesfehérvár környékén ritka Hamearis lucina. Jellemző fajok a Melitaea phoebe, a Plebejus argyrognomon és a Boloria dia. Az erdős szakaszon elöször 2016-ban figyeltem meg a Parnassius mnemosyne és a Hipparchia fagi fajokat, melyek nagyobb mennyiségben a szomszédos Malom-hegyen tenyésznek. A gyalogbodzás, szedres erdőszegélyeken több védett faj élöhelye található: Brenthis daphne, 
Satyrium w-album, S. spini és $S$. pruni.

A víztározó alatt a völgy két kisebb magaslat között halad át. A Jézus-hegyen löszgyepeket és felhagyott gyümölcsösöket találunk. Itt tenyészik a Zerynthia polyxena, ritkább, védett fajok még a Satyrium spini és a Lycaena thersamon. A száraz gyepek jellemző fajai fordulnak elő leginkább, úgy mint a Polyommatus bellargus, a P. coridon, az Aricia agestis, az Iphiclides podalirius és a Pontia edusa, valamint itt is nagy tömegben fellépö Melanargia galathea.

A Malom- vagy Körakás-hegyen erös populációja él az erdőben a Parnassius mnemosyne és Coenonympha arcania fajoknak, megtalálható a Hipparchia fagi. 2017-ben itt jelent meg a Melitaea trivia első két, a város területén észlelt példánya.

\section{Csalai-erdö}

A területen sikerült kimutatni a védett Satyrium ilicis és a $S$. pruni fajokat. Tömeges a Lycaena tityrus, a Coenonympha arcania, az Issoria lathonia és itt találjuk a védett Parnassius mnemosyne másik, igazán erőteljes népességét.

A Nymphalis polychloros mind tavasszal, mind júniusban megfigyelhető, vele egy időben kedvező években szép számmal repül a Lybithea celtis, a Araschnia levana, a Polygonia c-album, a Vanessa atalanta és a V. cardui. A szederbokrokon helyenként itt is megjelenik a Brenthis daphne, 2016-ban egy-egy példány Aporia crataegi és Hamearis lucina is elökerült.

A szemeslepkék közül említésre méltó a Hipparchia semele, H. fagi, Brintesia circe együttes előfordulása.

Az erdő délen a zömmel Pákozdhoz tartozó, birkalegelőként használt Zsellér-legelővel határos. Az erdő cserjés szegélyén többek között előfordul az Iphiclides podalirius, a Parnassius mnemosyne és az Argynnis pandora. A legelö faunája az intenzív legeltetés miatt sajnos szegényes, de 2017 májusában egy-egy példányban a Callophrys rubi és a Melitaea trivia is előkerült, rajtuk kívül a Spialia orbifer élőhelye is itt található.

\section{Császár-víz völgy középsö szakasz, Murvás-hegy}

A terület füzesei mentén és a régi Székesfehérvár-Bicske vasúti sínek környékén gyakori az Apatura ilia, nedves talajfoltokon gyakran láthatjuk vele együtt a Libythea celtis, a Nymphalis io, ritkán a $N$. polychloros példányokat. A kaszálóréteken 2014-ben szép számmal lehetett látni az Argynnis pandora fajt, az egyik cserjés szakaszon elökerült a Satyrium pruni.

A Murvás-hegy növényzetnek megfelelően a dombon melegkedvelő lepkékkel találkozhatunk pl. Iphiclides podalirius, a Lycaena tityrus, L. phlaeas, Hipparchia semele, Arethusana arethusa, Coenonympha arcania, Minois dryas de ezen a környéken két alkalommal is sikerült megfigyelni a Székesfehérváron napjainkban igen ritkán előforduló Aporia crataegi példányait is.

\section{Csúcsos-hegy, Jancsár}

A hegytetőn még napjainkban is igen gyakori a Papilio machaon, melynek dombtetőző példányai együtt kergetőznek az itt szintén rendszeresen előforduló Iphiclides podalirius, Vanessa cardui, $V$. atalanta példányokkal, szintén itt rajzik a Lasiommata megera is. A nyolcvanas években még városszerte gyakori volt a Nymphalis urticae azonban az elmúlt évtizedekben teljesen eltünt, bár újbóli felbukkanása nem valószínütlen. A hegyoldal és a környező gyepek gyakori lepkéje az Arethusana arethusa, a Pontia edusa és az Aricia agestis. 1997-ben tünt fel elöször a Csúcsos-hegyen és környékén a Colias erate, éveken keresztül gyakori faj volt, azonban az elmúlt időszakban ritkábban figyelhető már meg. 2016 augusztusában a Lampides boeticus két hím példánya jelent meg a Csúcsos-hegyen, vele együtt első alkalommal észleltem itt Hipparchia fagi példányokat. 
A hegy mögötti száraz gyepekben tenyészik a Hipparchia semele, rajta kívül a Colias chrysotheme fajnak is van 1998-ból megfigyelési adata. A Jancsár egyik felhagyott bányájában ugyanebben az évben Lycaena dispar, Polyommatus coridon fajokat is megfigyeltem.

\section{Sóstó és Homokbánya TT.}

Sóstó lepkefaunáját a hatvanas években SzEöKe (2016) kezdte el kutatni. Eredményei közül kiemelendő a Neozephyrus quercus, a Satyrium w-album, S. ilicis, a Cupido alcetas, a Glaucopsyche alexis, a Cyaniris semiargus, a Lycaena dispar rutilus, a Nymphalis antiopa, a Nymphalis polychloros valamint az Apatura ilia kimutatása.

BANIzs et. al. (2010) a Parnassius mnemosyne elöfordulását jelzik a Sóstóról írt monográfiában.

Jelenleg a lepkék között is a meleg és szárazságkedvelö fajok dominálnak pl. Pontia edusa, Polyommatus bellargus, P.coridon, Brintesia circe, Arethusana arethusa, Minois dryas, Lasiommata megera, Melanargia galathea.

A közelmúltban a fent felsorolt, SzEöKE (2016) által jelzett fajok többsége már nem került elö, ugyanakkor még mindig megtalálható a Glaucopsyche alexis és a Satyrium spini, újabban megtelepedett a korábban nem észlelt Argynnis pandora.

\section{Alsóvárosi-rétek (Demkóhegy), Maroshegy}

Demkóhegy és a rétek faunáját is Szeőke Kálmán vizsgálta elsőként. Megtalálta Pieris ergane egy példányát, amely valószínúleg a Keleti-Bakonyból elsodródott egyed volt. A városban kizárólag Maroshegyről és Demkóhegyröl került elö a Polyommatus dorylas, innen és a Szárazrétről a Pseudophilotes schiffermuelleri. Szintén jelentős a Satyrium ilicis és Cupido decolorata előfordulása.

A Maculinea teleius Demkóhegyi megtalálása is SzeöKe (2016) nevéhez füződik, ugyanakkor 2012-ben kiderült, hogy Maculinea nausithous is tenyészik a vérfüben gazdag réteken. Jelenleg a rétek két pontján találjuk meg együtt a két fajt, amelyek közül a M. teleius jóval gyakoribb és nagyobb területen fordul elő. Meg kell azonban említeni, hogy a rétek és ezzel együtt a lepkék jelenlegi helyzete egyáltalán nem megnyugtató. A vérfüben gazdag gyepek a házak közvetlen közelében terülnek el. A város korábban erdősíteni tervezte a gyepeket, amelyek jelenleg részben városi, részben magántulajdonban vannak. A tulajdonosok évről évre eltérő időpontokban kaszáltatnak, így 2013-ban a keleti, 2016-ban a nyugati rétet kaszálták le a Natura 2000 fajok repülése közben vagy közvetlenül elötte. Ráadásul tervek vannak a Székesfehérvár-Veszprém vasútvonal két sínpárra való bővítésére, ami az építkezéssel járó földmunkákkal a legértékesebb lelőhelyek teljes megsemmisülését okozná. Időközben megindult a rétek, illetve a maroshegyi Ốsmocsár és környékének helyi védelem alá vonása, amely talán lehetővé teszi az élőhely, valamint a két védett faj hosszú távú fennmaradását.

SzEÖKE (2016) Maroshegyen többek között megtalálta a Satyrium spini, S. pruni, a Thecla betulae, a Cupido decolorata és a Brenthis hecate fajokat.

A veszprémi vasútvonallal párhuzamosan kisebb kiterjedésben, de ebben a városrészben is többfelé vérfüves láprétek maradtak fenn, amelyeken a Maculinea teleius és a Lycaena dispar rutilus él.

\section{Sárpentelei-erdö}

A Sárpentelei-erdő a város legjobban kikutatott területének számít, ahol SzEÖKE KÁLMÁN a hatvanas években kezdett el tevékenykedni. Az általa gyüjtött fajok közül a leginkább nevezetes a környéken máshol nem található Euphydryas maturna, melynek egy példányát 1989-ben még én is láttam. Hasonlóan meglepő adat a Chazara briseis régebbi előfordu- 
lása. Csak az erdöből került elö a város környékéröl a Carterocephalus palaemon. Az erdőből Szeőke által kimutatott fajok: Aporia crataegi, Neozephyrus quercus, Thecla betulae, Satyrium w-album, S. spini, S. ilicis, Cupido alcetas, C. decolorata, Pseudophilotes schiffermuelleri, Glaucopsyche alexis, Cyaniris semiargus, Melitaea cinxia, Brenthis hecate, Nymphalis polychloros, Nymphalis antiopa, Hipparchia fagi. Mind SzEöKE (2016), mind saját kutatásaim során csak az erdőből sikerült kimutatni a Melitaea athalia fajt, míg az Argynnis aglaja tenyészése saját bejárásaim során bizonyosodott be.

A felsorolt fajok nagy része ma már valószínüleg nem talál megfelelő élöhelyet a teljesen záródott erdőben, a szegélyeken ugyanakkor még mindig előfordul az Apatura ilia és a Libythea celtis, az elmúlt években pedig itt is megjelent az Argynnis pandora.

\section{Gaja-patak, Palotavárosi-tavak}

A patak mentén a Zerynthia polyxena a város területén található legerösebb populációja tenyészik.

A patak közelében létesítették a Palotavárosi-tavakat, a Gaja mellékága és a Malomárok között egy időnként tocsogós, vérfüves láprét folt fekszik, ahol megtalálható a Maculinea teleius, M. nausithous valamint a Lycaena dispar rutilus faj is.

\section{Feketehegy}

A nyolcvanas évek végén még tenyészett itt egy Colias chrysotheme populáció, amelynek élőhelye a város terjeszkedése miatt mára csak töredékében maradt fenn.

A legértékesebb gyepfolt a hobbikertes rész és az új elkerülő út között elhelyezkedő Csóri-dülö. A Sárrét maradványaként egy rendszeresen kaszált láprétet is rejt a terület, vérfüvel és a Maculinea nausithous szép számú előfordulásával. Természetesen testvérfaját, a Maculinea teleius is megtaláljuk vele együtt. Sajnos 2017-ben a területet bekerítették, intenzív legeltetés kezdődött a vérfüves réteken, így mind a további kutatás, mind a hangyaboglárkák fennmaradása bizonytalanná vált.

A láprét szomszédságában száraz gyepeket, legelőket fedezhetünk fel, amelyek faunája csak kevéssé ismert, de többek között elökerült a védett Lycaena thersamon, a Melitaea trivia, a Polyommatus coridon és a Brintesia circe.

\section{Gólya-dülö, Nyúl-dülö}

A SzEÖKE (2016) által a száraz élőhelyeken megtalált lepkefajok közül a legfontosabb a Pyrgus serratulae, a Pieris ergane és a Chazara briseis. A Gaja szakaszán került elö elöször a Zerynthia polyxena. Helyileg jelentős fajok a Cupido decolorata, a Pseudophilotes schiffermuelleri, a Glaucopsyche alexis, a Cyaniris semiargus, a Maculinea teleius, a Satyrium spini, a S. ilicis és a Hipparchia fagi.

Staudinger István (DINP) hívta fel a figyelmemet a Nyúl-dülö nedves gyepjeire, amely nemcsak a Maculinea teleius, hanem a M. nausithous lelöhelye is. Szerencsére a láprétek a lakott területtől távolabb helyezkednek el és a két faj magas egyedszámban, zavartalanul tenyészik, így itteni fennmaradásuk jelenleg nincs veszélyben. További élöhelyeik fellelhetők a Móri-árokban, a Gaja-patak és a Móri-víz mentén (saját megfigyelések).

A Gólya-dülő erdejében gyakori a Coenonympha arcania, ugyanitt néhány példány Satyrium pruni fajt is megfigyeltem 2017 májusában.

A Nymphalis urticae utolsó példányát 1999 kora tavaszán a halastavak közelében találtam. 


\section{Védett, Natura 2000 és helyileg jelentős fajok}

Pyrgus serratulae - Országosan is igen ritka faj, amelynek alig néhány újabb keletü megfigyeléséről van tudomásunk (GERGELY et al. 2017). SzEŐKE (2016) 2000 óta csak a Sárpentelei-erdőből jelzi. A populáció jelenlegi megléte országos jelentőséggel bír. Melegkedvelö faj, visszaszorulásának oka nem ismert. Májustól júliusig egy nemzedékben láthatjuk. Védett faj.

Spialia orbifer - Középhegységeink déli lejtőin élő melegkedvelő faj. Megfigyeléseim alapján a Vértesben helyenként gyakori, elterjedt a Velencei-hegységben is. Az utóbbihoz tartozó, a Csalai-erdő déli szegélyén elterülö Zsellér-legelő dombjain PákozdSzékesfehérvár közigazgatási határán figyeltem meg néhány példányát 2017. 05. 14-én. Két nemzedéke van évente, melyek április közepétől június elejéig és július közepétől szeptember elejéig láthatók. Védett faj.

Zerynthia polyxena - A város területén jelenleg három populációját ismerjük. A Gajapatak mentén él a legnagyobb népessége, itt április-május fordulóján a biotóp domináns faja lehet. Szükebb területen találjuk a Rác-völgyben, a völgy alján egy rendszeresen kaszált löszgyepben és a Jézus-hegyen, egykori gyümölcsös helyén kialakult száraz gyepben, de ezeken a helyeken sem ritka. Területi védelemben csak a Rác-völgyi populáció részesül, így lokalitása következtében veszélyeztetett faj. Megfigyeléseim szerint a környéken igen ritka a Velencei-hegységben (Nadap) és a Keleti-Bakonyban, lokális, de helyenként gyakori a Vértesben és a Mezőföldön. Egyetlen nemzedéke április közepétől május közepéig-végéig repül. Védett, Natura 2000 faj.

Parnassius mnemosyne - Sóstói előfordulását, ahol BANIzs et al. (2010) szerint nem stabilan előforduló faj, eddig nem sikerült igazolni. Hazánkban sík vidéken csak kevés helyen fordul elö, a Mezőföldön egyedül Vajtán, a Nagy-erdőben találtam egy erőteljes népességét, ezért a Sóstói populáció megléte nagy jelentőséggel bírna. Megfigyeléseim alapján a Velencei-hegységben helyenként gyakori, szép populációja él a Csalai-erdő Kovács-berke területén. Szintén gazdag népessége tenyészik ettől északra, a Malomhegyen tölgyesben és akácosban. A Császár-víz völgyében is megfigyeltem egy-egy példányt 2016.05.08-án, majd 2017 májusában két alkalommal is. Egynemzedékes, Székesfehérváron május elejétől június elejéig repül, magasabb hegyvidékeinken akár júliusig látható. Védett, Natura 2000 faj.

Pieris ergane - A sziklai fehérlepke hazánkban kizárólag a Dunántúli-középhegység ritkasága. Székesfehérváron SzEöKE (2016) találta egy-egy példányát Demkóhegyen és Szárazréten, amelyek valószínűleg a Keleti-Bakony, vagy a Vértes déli lejtőiről sodródtak el, ahol helyenként napjainkban sem ritka. Legközelebbi előfordulása Csóron van, ahol helyenként gyakori. A Velencei-hegységből eddig nem mutatták ki (PETRICH 2001), ennek ellenére előfordulása nem kizárt, így a város keleti határának száraz gyepjeiben is van némi esély előkerülésére. Évente három nemzedéke repül április közepétől szeptember közepéig. Védett faj.

Colias chrysotheme - Előfordulása már Kovács (1953) fauna katalógusában is szerepel. Az Aszal-völgyi löszgyepben élő populációt 2010 őszén fedeztem fel, ezt követően előkerült a Rác-völgyből is. Ezen a két helyen stabil állománya él, megfigyeléseim szerint főleg csapadékosabb időszakokat követően (2010, 2012 augusztusa) látható nagyobb mennyiségben, amikor a száraz gyepek nincsenek kiégve és virágokban gazdagok. 
Az imágók aktív viráglátogatók, kedvelik többek között az aszat és a vajvirág nektárját. Az Aszal-völgyben peterakását is megfigyeltem. Régebben a város több pontján is előkerült: a nyolcvanas évek végén Feketehegyen egy azóta már részben beépített gyepben nem volt ritka, 1998. 05. 15-én a Csúcsos-hegy mögötti Jancsár száraz rétjén figyeltem meg egy példányát. A környéken (BÁLINT et. al. 2006) régi adatai vannak Sárkeresztúrról és a Velencei-hegységből, Petrich (2001) Dinnyésen gyüjtötte. A Mezőföldön erős populációit találtam Székesfehérvártól nem messze délre a Belsőbárándi Tátorjános TT-en, valamint a Táchoz tartozó, a megyeszékhely közigazgatási határához közeli Fövenypusztán is. Észleléseim alapján a Keleti-Bakonyban helyenként gyakori, a Vértesben igen ritka. Áprilistól novemberig repül négy nemzedéke, de az egyes nemzedékek csak igen rövid ideig láthatóak. Fokozottan védett faj.

Lycaena dispar rutlius - Leginkább nedves rétekhez kötődő faj, de főleg második nemzedéke kóborló hajlamú, így néha száraz területeken is felbukkan. A városban lápés nedves kaszálóréteken sokfelé megtalálható, de nem tömeges. Atipikus előfordulásai közé tartoznak a Nagyszombati utcához közeli felhagyott kőbányában 1998. 08. 02-án és az Aszal-völgyben 2015. 09. 14-én észlelt példányok. Megfigyeléseim szerint a város területén Maroshegy és környékének nedves rétjein a leggyakoribb. Kétnemzedékes: május közepétől július elejéig, majd augusztusban és szeptemberben repül, de hosszú, meleg öszökön (mint például 2011, 2015) egy harmadik nemzedék is megjelenhet szeptember második felében és októberben, ami feltünően kis méretü példányokból áll. Védett, Natura 2000 faj.

Lampides boeticus - Hazánkban igen ritkán előforduló, a mediterrán vidékekről északra vándorló faj. Magyarországon mintegy húsz éves szünet után 2014 őszén találták a Dél-Dunántúl néhány pontján,. (GERGELY et al. 2017) 2015-ben nem került elö. 2016.08.20-án a Csúcsos-hegyen két példányát észleltem és fotóztam. A lepkék több napig a hegyen tartózkodtak. Megfigyeléseim szerint territóriumot tartottak, leginkább kiemelkedő füszálak tetejére ültek le, egymást gyakran heves intenzitással kergették el. Főleg kora délelőtt virágokra is leszálltak táplálkozni. Még 08. 27-én is megfigyeltem legalább egy imágót. Az év hátralevő részében többen is sikerrel keresték a Balatonfelvidék, elsősorban a Tapolcai-medence tanúhegyein és a Villányi-hegységben (GERGELY et al. 2017). Mivel tápnövénye, Colutea arborescens (BARTHA et al. 2015), alapján a város környékén nem, legközelebb csak a Velencei-hegység keleti részén terem, itteni tenyészése és esetleges megtelepedése valószínütlen. Nem védett faj.

Pseudophilotes vicrama - Melegkedvelö, sziklagyepekben és száraz réteken élő lepke. Fehérvárról csak 2000 elötti adatai ismertek Szárazrétről, Demkóhegyről és a Sárpenteleierdőből (SzEŐKE 2016). Újabb megfigyelései a megyében csak a Vértesből és a Velencei-hegységből vannak, ahol PeTRICH (2001) adata nyomán hiába kerestem a Pogánykőnél, megtaláltam azonban Nadap mellett a Csúcsos-hegyen. Kétnemzedékes, április végétől szeptember elejéig repül. Védett faj.

Maculinea arion - Nagy termetü, jól repülő boglárkalepkénk, melynek előfordulása Kovícs (1953) faunajegyzékében szerepel Székesfehérvár helymegjelöléssel. A pontos lelöhely és a gyüjtő neve nem ismert. Az elmúlt hatvan évben nem került elö, legközelebb a Vértesben figyeltem meg. Felbukkanására esetleg a város keleti oldalán található dombokon lehet számítani. Védett, Natura 2000 faj. 
Maculinea teleius - A vérfü-hangyaboglárka a város környéki nedves, vérfüves rétek egyik legjellegzetesebb lepkéje. A város nyugati, a Sárréttel érintkező részén sokfelé előfordul, mint például Maroshegy és Demkóhegy több pontja, Feketehegy, Palotavárositavak. Ezeken az élőhelyeken általában gyakori. A keleti oldalon csak a Császár-víz völgyének nedves kaszálórétjén figyelte meg néhány példányát Kovács Gergely 2015. 08. 13-án. Egyes években, amikor tápnövényét nem kaszálják le repülési ideje közben vagy elött, kimondottan tömeges lehet. 2015. 08. 04-én hatalmas rajzása volt megfigyelhető az Alsóvárosi-rétek vérfüves szakaszain. A környéken lokálisan megtalálható a Mezőföldön, és a Sárréten északi irányban elterjedt a Móri-árok mentén beleértve a Nyugat-Vértest, de megtalálható Pátkától a Zámolyi-medencén keresztül a Csíkvarsairétig (Staudinger, Kovács G. és saját megfigyelések) . Egy nemzedéke július elejétől augusztus végéig repül, rajzásának csúcsa augusztus első felében van. Védett faj, Natura 2000 faj.

Maculinea nausithous - A sötétaljú hangyaboglárka a város egyik legnevezetesebb lepkéje, aminek elöfordulása csak 2010 után vált ismertté. Az hogy SzEőKE (2016) kutatásai során nem került elö, felveti egy jelenkori terjedés lehetőségét, amely a vérfüvel együtt történt vízfolyások, mint például a Gaja vagy a Malom-árok mentén. A feltevést alátámasztja az a tény, hogy 2017-ben Staudinger István (DINP) Váli-völgyi megtalálásáról tájékoztatott és megkerült a Gerecsében is. Fenti rokonától eltérően csak a város nyugati oldaláról ismerjük, jelenleg összesen négy lelöhelyről. Az előző fajnál ritkább az Alsóvárosi-réteken, körülbelül azonos mennyiségben találhatók Feketehegyen a Csóri- és a Nyúl-dülőben.

A Palotavárosi-tavaknál a két faj, a nagy tüzlepkével együtt közel fordul elő a megyeszékhely központjához, ami ekkora város esetén több mint figyelemre méltó. Északi és nyugati irányban a Móri-árokban és a Zámolyi-medencében az előző, rokon fajhoz hasonló elterjedést mutat, azonban a várostól délkeletre a Mezőföld síkján már sehol sem fordul elő, vagyis a nausithous Székesfehérváron éri el hazánkban elterjedésének délkeleti peremét. Eppen ezért populációinak megőrzése és lelőhelyeinek minél előbbi védetté nyilvánítása igen fontos feladatunk! Az imágók a M. teleius fajnál valamivel később, július közepén kezdenek repülni, rajzásuk augusztus végére befejeződik. Védett és Natura 2000 faj.

Polyommatus thersites - Rokonától, az igen gyakori Polyommatus icarustól való rendkívül nehéz elkülönítése miatt adathiányos faj, mely jó állapotú száraz gyepekben tenyészik és megfelelö élőhelyeken igen gyakori lehet (például a váci Naszály déli lejtőjén tömeges előfordulását észleltem). Fehérváron csak SzEőKE (2016) találta a nyugati rész néhány pontján. Petrich (2001) csak egyetlen helyröl jelzi a Velenceihegységből. Két nemzedéke májustól szeptemberig látható. Védett faj.

Libythea celtis - A nyolcvanas évek végén és a kilencvenes évek elején még igen ritka fajnak számított, majd egyre több helyen jelent meg és napjainkban bárhol felbukkanhat. Leginkább erdőszegélyeken, patakvölgyekben, erdei utak mentén láthatjuk, ahogy a nedves talajon összezárt szárnnyal szívogat, de egyre többször települések belterületén is megfigyelhetö, ahol tápnövénye a Celtis occidentalis elöfordul. Nagyobb rajzását először 1995. 06. 30-án, majd 2007. 05. 28-án észleltem a Sárpentelei-erdő szegélyében, később 2016. 06. 19-én a Kovács-berke köves útján volt gyakori. A frissen kelt példányok május végén, június elején kezdenek rajzani, majd július közepétől szeptemberig véleményem szerint egy második nemzedék látható. Utóbbi példányai esetenként még október-novemberben is repülnek. Áttelelés után a lepkék kora tavasztól újra aktívak, még májusban is megfigyelhetök. Védett faj. 
Euphydryas maturna - A díszes tarkalepke egyetlen kopott nőstény példányát 1989. 06. 12-én láttam és fotóztam a Sárpentelei-erdő északkeleti, nedvesebb részén. A fajt már SzEŐKE (2016) is megtalálta a hatvanas években. A csekély példányszámú populáció azóta a beerdősülés áldozatává vált. Legközelebbi populációit Vérteskozma környékén és a Dél-Mezőföldön Vajta, Németkér térségében védett erdőkben találtam A lepkék árnyékmozaikos-napos erdei utak mentén láthatók május-júniusban. Védett faj, Natura 2000 faj.

Brenthis hecate - SzEőKE (2016) csak 2000 elötti adatokat sorol fel, ezért is örömteli, hogy 2015. 06. 14-én egy példányt figyeltem meg és fotóztam a Rác-völgy északi, cserjés szakaszának egy tisztásán. PETRICH (2001) régebben a Velencei-hegység néhány pontján találta (Pákozd, Sukoró), a Keleti-Bakony Fejér megyei részén csak Kincsesbányáról van adata (SZEÖKE et al. 1988), ugyanakkor megfigyeléseim alapján még napjainkban is elterjedt a Vértesben. Fehérváron igen ritka és veszélyeztetett faj. Egynemzedékes, május végétől, június elejétől július közepéig repül. Védett faj.

Argynnis pandora - Déli elterjedésü, nagytermetü mediterrán, hazánkban erősen fluktuáló faj. 2000 előtt egyetlen adata sem volt ismert Székesfehérvárról. Első említése a BANIzs et al. (2010) által a Sóstóról írt könyvben történt. Az elmúlt években elterjedt és sokfelé megtalálható. Megfigyeléseim szerint a Mezőföldön szintén nem ritka és előfordul Pákozd környékén is a Velencei-hegységben. Az imágó hosszú életű, már május végén megjelenik és egészen októberig látható. Védett faj.

Chazara briseis - Egyik leginkább veszélyeztetett, kipusztulás szélén álló lepkénk, amely elterjedési területének túlnyomó részéröl (GERGELY et al. 2017), az Eszakiközéphegység, Budai-hegység, Pilis, Kiskunság, Vértes, Dél-Dunántúl területéről már eltünt. Utolsó populációit a Keleti- és a Déli-Bakonyban, legközelebb Csór környékén figyeltem meg, valamint a Balaton-felvidék keleti részén is megtalálható még (GERGELY et al. 2017). Az imágók száraz réteken és sziklagyepekben élnek. Eltűnésének oka nem ismert. Székesfehérváron SzEőke (2016) találta valószínúleg elkóborolt példányait a Sárpentelei-erdőben és Szárazréten. PeTrich (2001) a Velencei-hegységben többek között Pákozdon, a Tompos-hegyen gyüjtötte, ami párszáz méterre található a megyeszékhely határától. Egy nemzedéke július közepétől szeptemberig repül. Védett faj.

Hipparchia fagi - A nyugati oldalról csak SzEŐKE (2016) régi adatai ismertek. A keleti oldalon 2016-ban került elö a Csalai-erdőből (Kovács-berke), ahol 07. 17-én az egyik domináns faj volt. Az említett évben a faj erős gradációja volt tapasztalható és olyan helyeken is megjelent, mint a Csúcsos-hegy (közel harminc év alatt elöször), vagy a Császár-víz völgye, ahonnan addig nem volt megfigyelési adata. 2017-ben már csak a Csalai-erdőben és a Malom-hegy tölgyesében találtam, amelyek stabil élőhelyet biztosítanak a faj számára. Adataim alapján a Velencei-hegységben nem ritka faj, a Mezőföld síkságáról azonban eddig nem mutatták ki (GERGELY et al. 2017) . Egy nemzedéke van, amely júniustól szeptember végéig repül. Nem védett. 


\section{Gyakorisági változások a vizsgált időszakban}

Megfigyeléseim alapján az elmúlt időszakban a lepkék egyedszáma folyamatosan csökkenő tendenciát mutat, néhány, kedvezőbb évet és a terjedőben lévő fajokat kivéve. Összehasonlítva a fajok gyakoriságát az 2000 elötti állapotokkal, megállapítható hogy több faj eltünt, vagy csak alkalmilag fordult elö: Cartherocephalus palaemon, Pieris ergane, Neozephyrus quercus, Pseudophilotes vicrama, Polyommatus dorylas, Euphydryas maturna, Melitaea athalia, Argynnis aglaja, Nymphalis urticae, Chazara briseis.

Rendkívül megritkultak, lehetséges, hogy eltüntek a következő fajok: Pyrgus serratulae, Cupido alcetas, Cyaniris semiargus, Nymphalis antiopa.

Számottevő állománycsökkenés következett be az alábbi fajoknál: Papilio machaon, Aporia crataegi, Satyrium acaciae, Satyrium w-album, Cupido decolorata, Glancopsyche alexis, Brenthis hecate, Melitaea cinxia, Arethusana arethusa.

Ugyanakkor több faj újonnan telepedett vagy jelent meg a vizsgált élőhelyeken: Colias erate, Lampides boeticus, Maculinea nausithous, Melitaea trivia, Argynnis pandora.

Jelentősen gyakoribbá váltak a következő fajok: Satyrium pruni, Maculinea teleius, Aricia agestis, Libythea celtis, Melitaea phoebe, Apatura ilia, Coenonympha arcania , Minois dryas, Brintesia circe.

A fentiek alapján látható, hogy 23 faj tünt el vagy ritkult meg lényegesen, ugyanakkor 14 jelent meg vagy vált gyakoribbá.

\section{Köszönetnyilvánítás}

Szeretném köszönetemet nyilvánítani mindazoknak, akik az adatgyüjtésben és a közlemény megírásában segítségemre voltak, külön kiemelve dr. Szeőke Kálmánt, aki nem publikált adatait rendelkezésemre bocsátotta és hasznos tanácsokkal látott el, valamint Gór Ádámot, aki a nyelvi, formai és taxonómiai korrekciót végezte és a fajok meghatározásában sokat segített. Ezenkívül köszönet jár Kovács Gergelynek (Völgy-híd Természetvédelmi Alapítvány) jelen cikk elözményének az alapítvány blogján való megjelenésének biztosításáért és a megfigyeléseiről való rendszeres tájékoztatásáért, dr. Gergely Péternek a határozásban és Staudinger Istvánnak (DINP) a terepi munkában nyújtott segítségéért . Édesanyámnak a terepi kutatásokhoz az évek során nyújtott „logisztikai” támogatását szeretném külön megköszönni. 


\section{Irodalom}

BÁLINT Zs. 1994: Magyarország nappali lepkéi a természetvédelem tükrében. - Somogy Megyei Múzeumok Közleményei 10: 183-206.

BÁLINT Zs. 1996: A Kárpát-medence nappali lepkéi 1. Pillangófélék, fehérlepkefélék, boglárkalepke-félék, mozaiklepke-félék. - Magyar Madártani és Természetvédelmi Egyesület, Budapest, 183 pp.

Bálint Zs., Pitter G. \& Gubányi A. 2006: Magyarország védett pillangóalakú lepkéinek katalógusa a Magyar Természettudományi Múzeum gyűjteményei alapján. - Magyar Természettudományi Múzeum, Budapest, $136 \mathrm{pp}$.

Banizs K. 2008: Székesfehérvár zöld arca. - KL Média, Székesfehérvár 220 pp.

Banizs K., Mező É. \& TAKÁCs A. 2010: A Székesfehérvári Sóstó természetvédelmi terület. - BOCS Alapítvány, Székesfehérvár 304 pp.

BARINA Z. 2008: Adatok a Dunántúli-középhegység és környéke flórájához. - Flora Pannonica 6: 3-23.

Bartha D., Király G., Schmidt D., Tiborcz V., Barina Z., Csiky J., Jakab G., Lesku B., Schmotzer A., Vidéki R., Vojtкó A. \& Zólyomi Sz. (szerk.) 2015: Magyarország edényes növényfajainak elterjedési atlasza. - Nyugat-magyarországi Egyetem Kiadó Sopron, 329 pp.

Dietzel Gy. 1997: A Bakony nappali lepkéi. Regionális Vörös Könyv. - A Bakony Természettudományi Kutatásának Eredményei 21: 1-200.

DövÉNYI Z. (szerk.) 2010: Magyarország kistájainak katasztere. - MTA Földrajztudományi Kutatóintézet Budapest, 2. átdolgozott és bővített kiadás.

Gergely P., Gór Á., Hudák T., Ilonczai Z. \& Szombathelyi E. 2017: Nappali lepkéink - Határozó terepre és természetfotókhoz. Kitaibel Kiadó 264 pp.

GozmÁnY L. 1968: Nappali lepkék - Diurna. - Magyarország Állatvilága (Fauna Hungariae), Akadémiai Kiadó Budapest, 16(15): 1-204.

HudÁk T. 2017: Nappali lepkék Székesfehérváron. - Madártávlat 24(3): 38-43.

KirÁly G., Molnár Zs., BölöNi J., Csiky J. \& VoJtKó A. 2008: Magyarország földrajzi kistájainak növényzete. - MTA ÖBKI, Vácrátót 248 pp.

Kovács G. K. 2015a: Észak-mezőföldi löszmaradványok. - Természet Világa 146(2): 78-81.

KovÁcs G. K. 2015b: Észak-Mezőföld patakvölgyei. - Természet Világa 146(10): 462-465.

Kovács G. K. 2017: Rejtőzködő löszvölgyek: a koronázóváros élő ékességei Természetbúvár 72./6: 22-25.

Kovács L. 1953: A magyarországi nagylepkék és elterjedésük. - Folia entomologica hungarica 6: 76-165.

Kovács L. 1956: A magyarországi nagylepkék és elterjedésük. - Folia entomologica hungarica 9: 89-140.

LAfranchis, T. 2007: Butterflies of Europe. New Field Guide and Key - Diatheo Paris 351 pp.

Lendvai G. \& Horváth A. 2011: Adatok a Mezőföld löszflórájához II. Kitaibelia 15(1-2): 119-132.

Petrich K. 2001: A velencei táj lepkevilága. - Mezőgazdasági Szaktudás, Budapest 306 pp.

SlamkA, F. 2004: Die Tagfalter Mitteleuropas - Östlicher Teil. Bestimmung - Biotope Und Bionomie Verbreitung - Gefährdung. - Bratislava 288 pp.

Szabóky Cs., Samu F., Szeőke K. \& Petrányi G. 2014: Simontornya lepkevilágáról (Lepidoptera). In: Simontornya ízeltlábúi. - Magyar Biodiverzitás-kutató Társaság, Budapest p. 143-186.

SzeÖKe, K. SzeöKe, L. \& NyíRö, M. 1988: Results of the investigations on the Lepidoptera fauna of the Eastern Bakony Mts. - Folia Historico-naturales Bakonyiensis 7: 133-156.

SzEŐKE K. 2016: Székesfehérvár nappali lepkéi 1965-2016. - (kézirat - manuscript)

SzEÖKE K. 2007: A Vértes-hegység lepkefaunája (1971-1985) (Lepidoptera: Macrolepidoptera). - Natura Somogyiensis 10: 341-360.

TAKÁCs A. 2009: Gánt-Gránás és környékének lepkéi. - Folia Historico-naturales Bakonyiensis 26: 141-170.

VARGA Z. (ed.) 2010: Magyarország nagylepkéi (Macrolepidoptera of Hungary). - Heterocera Press Budapest, $253 \mathrm{pp}$.

WeidemanN, H. J. 1988: : Tagfalter, Entwicklung-Lebensweise, 1-288. Bd. 2: Tagfalter, Biologie - Ökologie - Biotopschutz. - Neumann - Neudamm, Melsungen 1: 1-372. 
